Res Mobilis

Revista internacional de investigación en mobiliario

y objetos decorativos

Vol. 7, nº. 8, 2018

\title{
ITALY CREATES. GIO PONTI, AMERICA AND THE SHAPING OF THE ITALIAN DESIGN IMAGE \\ ITALIA CREA. GIO PONTI, AMÉRICA Y LA CONFIGURACIÓN DE LA IMAGEN DEL DISEÑO ITALIANO
}

Elena Dellapiana*

Politecnico di Torino

\begin{abstract}
The paper explores transatlantic dialogues in design during the post-war period and how America looked to Italy as alternative to a mainstream modernity defined by industrial consumer capitalism.

The focus begins in 1950, when the American and the Italian curated and financed exhibition Italy at Work. Her Renaissance in Design Today embarked on its three-year tour of US museums, showing objects and environments designed in Italy's post-war reconstruction by leading architects including Carlo Mollino and Gio Ponti. The exhibition was hugely popular; celebrated by the public and critics as expressing Italy's continuing "unity of the arts" and a combination of craft tradition and design innovation that offered an alternative modernity to America's all-out industrialization. The exhibition led to the production and retail of Italian-designed wares by several US firms, contributing to Italian design's popularity in the States and shaping, through Gio Ponti's action too, an image shared nowadays.
\end{abstract}

Key Words: Italian post-war Design, Gio Ponti, Italian Design in United States, Made in Italy, Building Identity

\section{Resumen}

El artículo explora los diálogos transatlánticos en el diseño durante el periodo de postguerra y la manera en que América miró a Italia como alternativa a la corriente convencional definida por el consumo industrial capitalista.

Se inicia en 1950, cuando los americanos y los italianos comisariaron y financiaron la exhibición Italy at Work. Her Renaissance in Design Today embarcada en un tour de tres años por los museos Americanos, enseñando objetos y ambientes diseñados en la Italia de la reconstrucción postbélica por destacados arquitectos incluyendo Carlos Mollino y Gio Ponti. La exposición fue

\footnotetext{
*E-mail: elena.dellapiana@ polito.it
} 
extremadamente popular; celebrada por el público y los críticos como expresión del constante "unidad de las artes" italiana y la combinación de la tradición artesana y la innovación del diseño que ofrecía una alternativa a la modernidad a es industrialización fortísima de América. La exposición orientó la producción y la venta al por menor del diseño italiano a varias firmas americanas, contribuyendo a la popularidad del diseño italiano en Estados Unidos y se configuró, también a través del trabajo de Gio Ponti, una imagen que se mantiene hoy día.

Palabras clave: Diseño de la postguerra Italiana, Gio Ponti, Diseño italiano en Estados Unidos, Made in Italy, Construcción de identidades.

\section{Introduction}

The subtitle of this paper could be: was Gio Ponti the mastermind behind the image of Italian Design in post-war America? Eventually it aims to link the role that Ponti played in Italy from the Twenties to the post-war years, the perception that American culture had of this and, sewing the two histories, the shaping of the multifaceted image of one of the most important national design culture thanks to American financial and political interventions, cultural and commercial promotions.

The question arises from the fact that most examples of Italian projects in the USA are, in many ways, related to Ponti, even though he was often hidden behind organizations, magazines, exhibitions and committees ${ }^{1}$.

At the very beginning, one of the first great examples of commercially successful Italian manufacture is also somehow related to him: the large number of items and huge quantity of transoceanic deliveries during the Twenties were focused on ceramics. (Fig. 1) Divine, bright tableware from the Perugia district and gold-decorated porcelain created for American tycoons urged new ceramic industrialists to hire "artistic managers" 2 . As was already the case in English and French manufacture (see Chistopher Dresser or Eugène-Victor Collinot), Italian companies also had their own technicians/artists but, unlike those countries which had introduced applied arts training for employees, the choice was limited to architects, the only figures who seemed able to merge the project with the production process.

In 1923, Ponti was the artistic manager for Richard-Ginori industries, working in luxury porcelain and everyday ceramic objects and Guido Andlovitz, an architect who graduated in architecture at the Politecnico di Milano ${ }^{3}$, was in Lombardy, managing SCI (Società Ceramica Italiana, Laveno) which produced more contemporary objects. Both were appointed the tasks of designing and supervising the entire project, production and sales process, pushing the enterprises to a high level in terms of quality and quantity of pieces sold. 


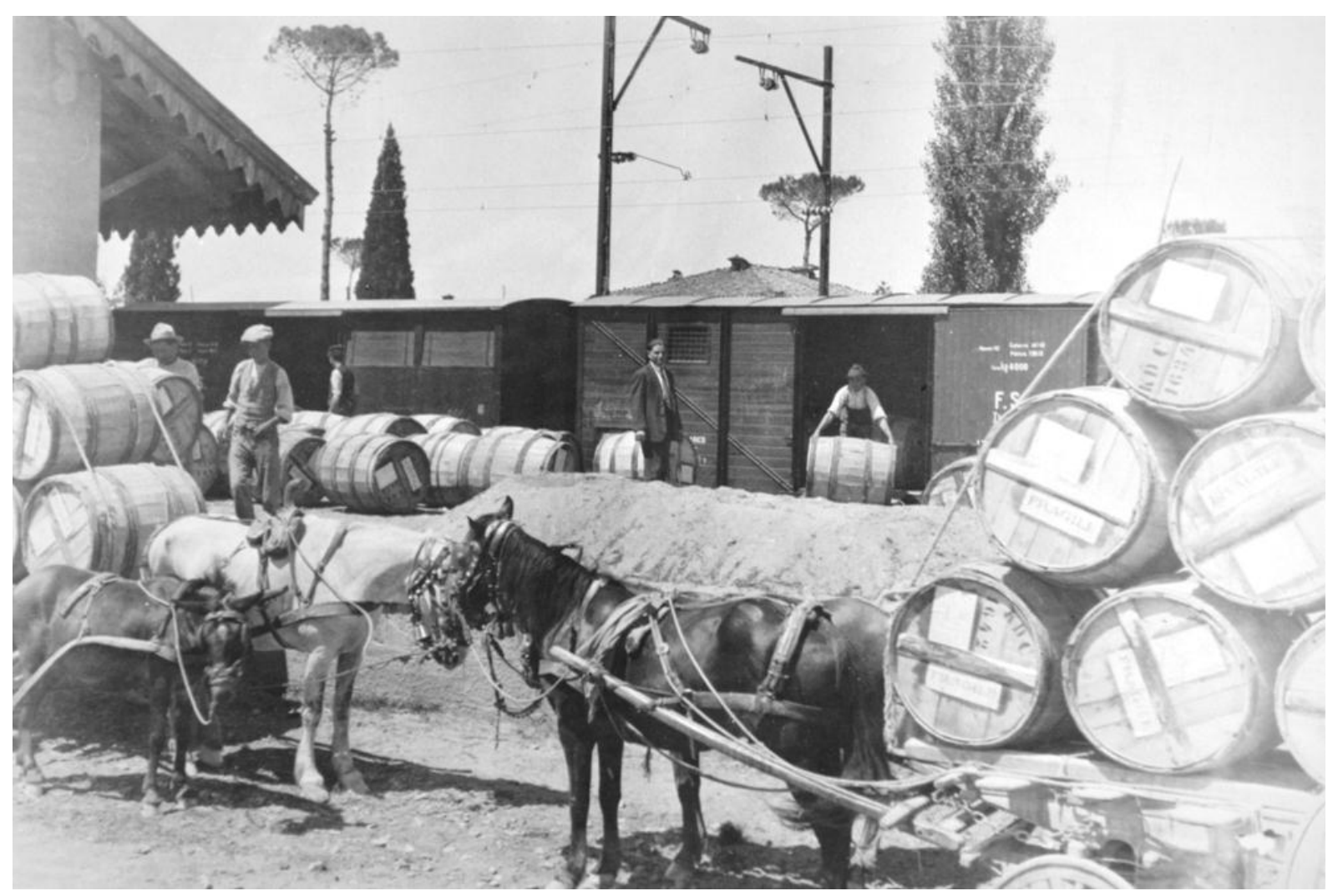

Fig. 1. Shipment of ceramic sets "lustro" decorated to the United States, ap. 1920 century, Grazia manufacture Archive, Deruta, Italy.

The attraction of this kind of objects lay in the merging of industry and craftsmanship, and its success gave Italian architects/designers the chance to experiment within their own traditions while also making use of new research being undertaken in art thanks to the Futurism and Abstractism movements as is clear from Andlovitz's designs which were mostly inspired by the Second Futurism, with charming tiny pictures of aviators, planes, ships and athletes ${ }^{4}$.

During the same period, the designers implemented the development of small industries producing metallic tubular components, new materials and so on, as was also occurring in other European countries, traditionally more related to the rational epitome, and bearing similar results ${ }^{5}$. These different aspects are to be seen as a whole, because people such as Ponti were interested in spreading craftsmanship, industrial production, art, music and literature in a typical humanistic approach which further affirmed itself during the Fascist period together with the rhetoric propaganda promoting the artisan above the worker in an almost "arts and crafts" perspective created to improve the feeling of national identity 6 .

\section{Spreading Italy: fine arts and commercial success}

This identity was also shaped, of course, by the Italian artistic tradition and, following this approach, the Fascist government attempted to export its 
image abroad, particularly to the US, where Italian modernity had already been introduced by the Monza Exposition Electrical House (1930) by Luigi Figini and Gino Pollini, shown on the occasion of the world-famous MoMA exhibition The International Style ${ }^{7}$. In contrast with this modernist approach, the Italian authorities also presented the rhetoric of the powerful Renaissance roots by promoting the travelling Exhibition Italian Masters lent by the Royal Italian Government (1940), with a further programme on modern art, which was never completed ${ }^{8}$.

In the immediate post-war period in US, the two sides (arts and crafts) of Italian culture were equally distributed, both in commercial contexts -as requested by political assets and bilateral agreements -and in cultural ones- in relevant cultural institutions like, among others, the MoMA or in specific association venues like the House of the Italian Handicraft.

In 1947 the CADMA association (Commissione Assistenza Distribuzione Materiali Artigianato) chaired by art historian Carlo Ludovico Ragghianti, promoted an exhibition entitled Handicraft as a Fine Art in Italy, hosted at the House of Italian Handicrafts, New York'. The exhibition, designed to "perfect the quality of Italian handicrafts through the collaboration between artists and craftsmen"10, exhibited almost exclusively paintings and sculptures including works by Lucio Fontana, Fausto Melotti, Renato Guttuso, Giorgio Morandi, pushing the idea of a mainly artistic production. This was coherent with the image diffused by the Americans after the Second World War with the USIS (United States Information System) programme in Europe and especially in Italy. One of the goals, together with the establishment of several cultural institutions in a country damaged by the war ${ }^{11}$, was the creation, on the other side of the ocean, of companies and associations: Handicraft Development Inc. and the House of Italian Handicrafts promoted by Max Ascoli, an ItalianAmerican worked to support in Italy and distribute in American market Italian products immediately following the initial success of the Allied Army in Italy in 1943.

In a memo entitled "What is Handicraft Development Inc.?" Ascoli listed statistical reasons for his choice to aid the diffusion of handicrafts in Italy:

"According to the official industrial census of 1937-1940, no less than 829,015 Italian enterprises, out of a total of $2,339,361$, were of artisanal nature. Out of 5,375,152 persons engaged in industrial occupations, 1,317,671 were artisans engaged in handicraft trades. Thus in terms of industrial occupation and employment, handicraft production was responsible for about $1 / 4$ of the total, and actually more if secondary employment in trade and other occupations is considered". ${ }^{12}$

His aims were clear: to support the Italian economic redevelopment with financial tools and, at the same time, to improve the cultural and production traditions in their most crucial artisanal aspects, which dated back to the Renaissance. This had somehow already been attempted by Italian intellectuals 
and politicians in the years immediately following the unity of Italy, in the last decades of the $19^{\text {th }}$ century with the goal of building a national identity ${ }^{13}$.

In this context, in 1949, MoMA promoted the exhibition Twentieth-Century Italian Art, curated by James Thrall Soby and Alfred J Barr Jr. ${ }^{14}$ (Fig. 2) intended as an outline of the new, democratic scenario of Italian art from the beginning of the century, as if Fascism had never existed. Schools and single authors were analysed and displayed: early Futurism, Metaphysics, and artists ranging from the 1920s until the war: Giorgio De Chirico, Carlo Carrà, Giorgio Morandi, Angelo Rossi and Antonio Donghi, Renato Guttuso, and also the timid attempts of Abstractionists (il Fronte nuovo delle Arti) ${ }^{15}$. They stated: "The climate for art is propitious in Italy just now, with the shackles of Fascist isolationism rusting empty on the ground, and we have sought - again without claim to finality - to indicate what direction the newer creative impetus is taking"16.

The exhibition was organized with the collaboration of new Italian functionaries such as Ranuccio Bianchi Bandinelli, director of Fine Arts at the Ministry of Education. Communication between the two ocean shores was therefore immediately established also in the field of decorative arts and involved design as well. Gio Ponti published in the June edition of Domus in 1949 an exchange of letters between himself and Alfred Barr on the catalogue Paintings and Sculpture in the Museum of Modern Art ${ }^{17}$, following his review published some editions earlier in which he complained about the lack of Italian $\operatorname{artists}^{18}$. Barr's answer referred to an intention to make new acquisitions..., if it was not too expensive and Ponti replied by imploring Italian painters and sculptors to lower their prices ${ }^{19}$. In any case, the promotion of arts seemed to be the main tool used to shape the idea of an Italian Renaissance ${ }^{20}$ together with the commercial approach already at work thanks to Max Ascoli's group ${ }^{21}$. Italian artistic tradition, both ancient and modern, was therefore the way to "weave" art, architecture and design together. The use of the words themselves (Renaissance, creativity, to create....) became a commercial claim and made up the titles of most of the art or design exhibitions and the first articles in popular and trade magazines. Ernesto Nathan Rogers, the director of the post-war version of Casabella magazine, was appointed in 1949 by Vogue America to describe - next to the pictures by Irving Penn - the Milan Renaissance and often mentioned therein the Italian artistic tradition (the Renaissance in particular) to explain the new Italian design culture following the dark times of Fascism ${ }^{22}$.

Something similar happened in the architectural field and in an operative sense. The UNRRA Casas programme ${ }^{23}$ conceived its financial help in building new towns, schools, and professional tools in an anti-communist view to attract consensus. Italian architects and designers took the financial support and several cultural and theoretical stimuli and turned them around in an original way ${ }^{24}$. Their work was perceived in the US as typical, almost folkloric, and deeply related to craftsmanship the promotion of which was intended to be the "rehabilitation of Italian handicrafts for export to the American market" 25. 


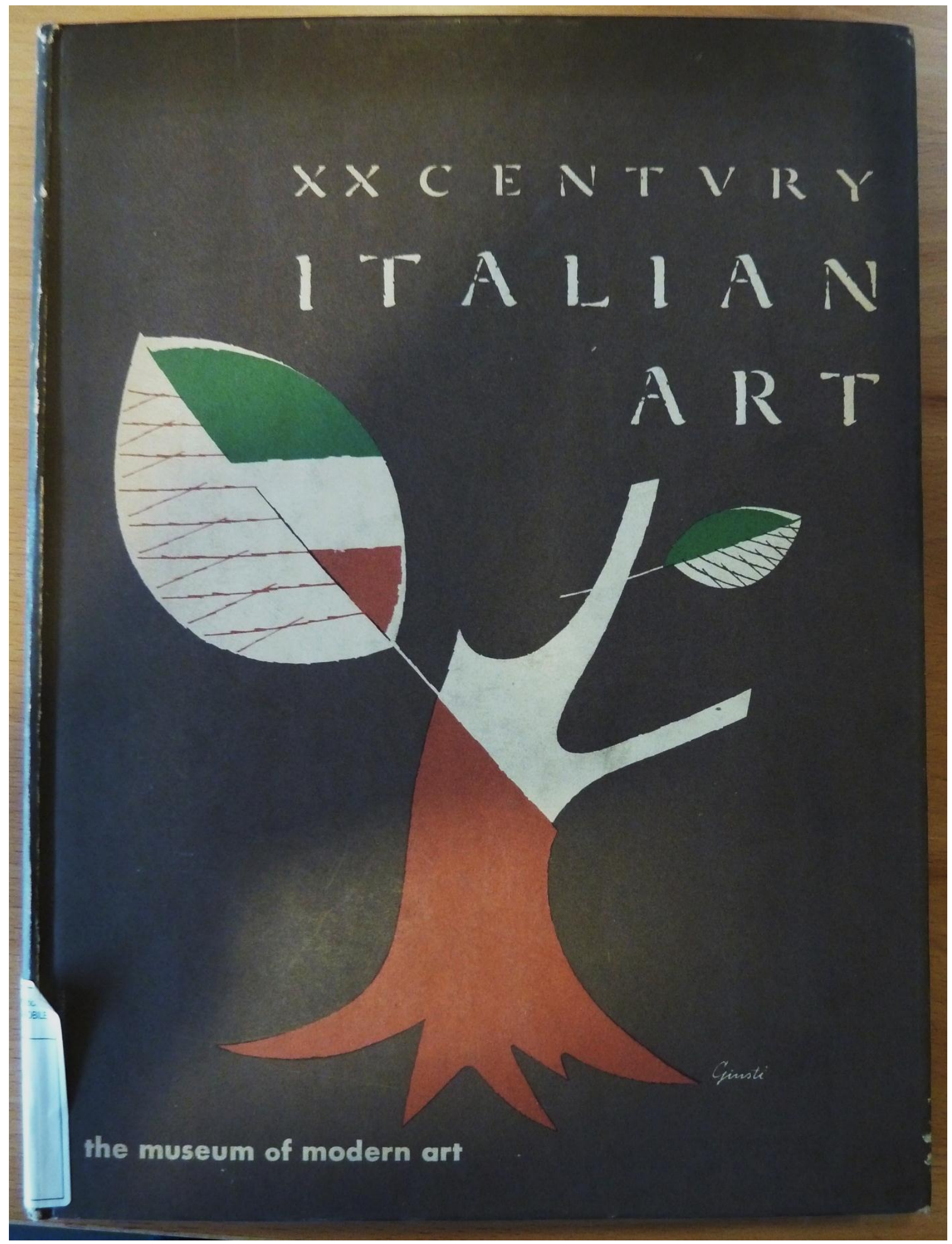

Fig. 2. Cover of the catalogue of the Exhibition, XX Century Italian Art, MoMA, 1949. Graphic by George Giusti (Central Architecture Library, Politecnico di Torino, Italy. 


\section{Italy at Work: (Ponti's?) Exhibition-Manifesto}

Therefore, these are the years and culture mediums behind the first large exhibition that aimed to show the re-birth of Italian production following the years of dictatorship and war. The seeds had been planted by the organization Committee with the Italian Ministry for Foreign Trade and many sponsors who financed and promoted the Italy at work [3] exhibition, by, once again, quoting the most glorious period of Italian History: the subtitle was Her Renaissance in Design Today. This MUSA (Mostre United States of America) exhibition crossed the United States from 1950 to 1953 in twelve different museums ${ }^{26}$.

The exhibition officially set its roots, as had been the case with the new architecture, in the Marshall plan, which, in addition to financing the emergence of housing and mere survival, created specialist libraries and cultural clubs throughout the main Italian cities in order to share projects and propaganda also inviting in the US, thanks to the Fullbright mobility programme, visiting architecture professors such as Bruno Zevi, Gino Valle, Angelo Mangiarotti ${ }^{27}$. Furthermore, more Italian designers were already in the US, covering pivotal roles, such as the Dutch-born but Italian-educated graphic designer and artist Leo Lionni, art director of Fortune since $1949^{28}$, or the young Naples-born designer Roberto Mango, who was already in Princeton in 194929; in turn, in the same year the BBPR firm designed the American pavilion in the Ninth Triennial of Milan, showing an outline of contemporary American architecture from $1947^{30}$. Another key role in the dissemination of the Italian project was played by Bernard Rudofsky, whose role as artistic director for magazines such as Architectural Review and, after 1945, Interiors followed a fruitful period in southern Italy during which he had collaborated with Italian architects as Ponti and Luigi Cosenza. He, consequently, edited an early special edition of "Interiors" in July 1948 dedicated to Italian furniture and interiors, uniting the very first architects and designers -often one and the same - with a furniture and interiors projects and production business ${ }^{31}$. To illustrate the pieces of furniture and furnishings, George Nelson praised the "noble aesthetic of poverty" in post-war Italian design, reflecting somehow the contemporaneous growth of the Neorealist poetry ${ }^{32}$.

Gio Ponti wasn't one of the authors considered in this "Interiors" dedicated edition, perhaps because he was still too removed from a modern-international taste, but it would be natural to believe that he was - as always, behind the scenes - the most influential brain behind the following Italy at Work exhibition, even if the organization committee was made up exclusively of American museum curators (Meyric Rogers from Chicago, Charles Nagel from Brooklyn) designers (Walter D. Teague with whom Ponti was in correspondence ${ }^{33}$ ) and officials (Ramy Alexander, vice-president of $\mathrm{CNA}^{34}$ and Ascoli's collaborator in Handcraft Development Inc). 


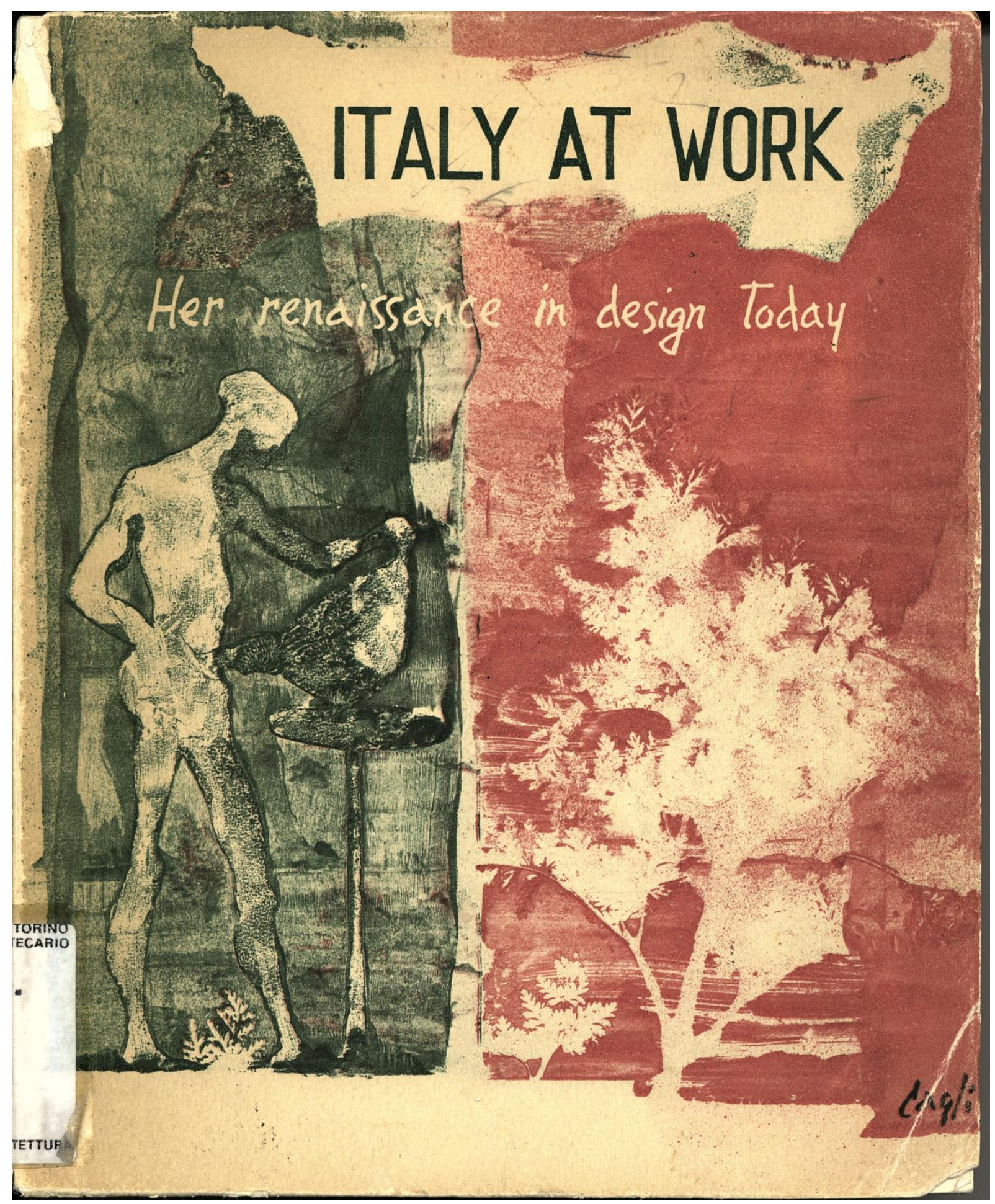

Fig. 3. Cover of the catalogue of the Exhibition Italy at work: her Renaissance in Design Today, Rome: 1950, graphic by Corrado Cagli, (Central Architecture Library, Politecnico di Torino, Italy. 


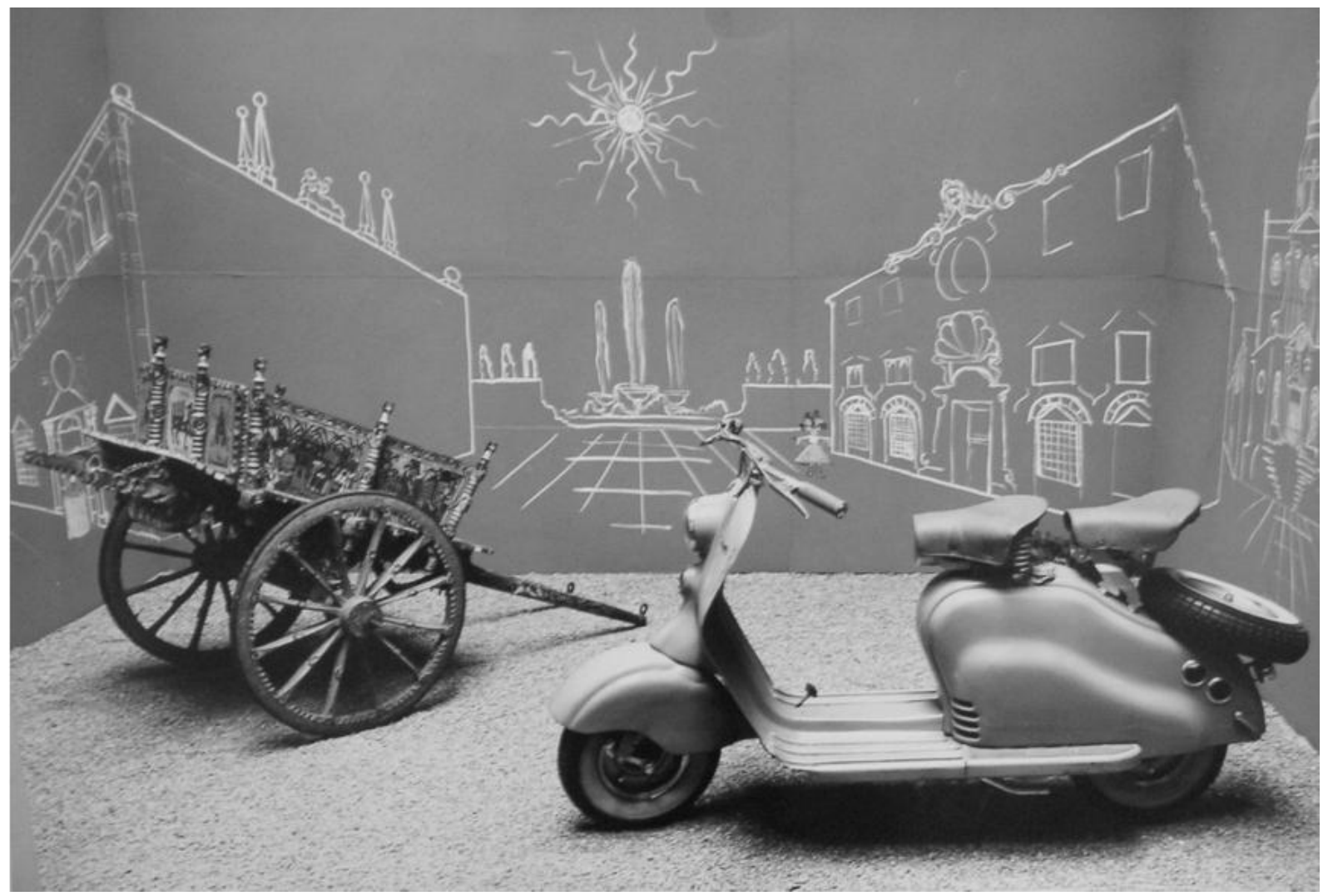

Fig. 4. Entrance hall of the Brooklin edition fo the exhibition Italy at work: her Renaissance in Design Today, 1950 (Brooklin Museum Archives, https://www.brooklynmuseum.org/opencollection/exhibitions/859

Thanks to his relationship, which included American public officers, journalists, industrialists, museum curators and university deans, the Milanese architect and director of Domus, a key member of the panels of several architecture competitions, and of the Milan Triennial, already had been among the European architects invited in 1928 by Macy's to design a "case study" dining room space (using materials and furniture already produced for the DOMUSNOVA series designed together with Emilio Lancia, produced by La Rinascente department store, and permanently exhibited there ${ }^{35}$. As well as an early correspondence with the New York-based furniture industry Altamira between 1935 and $1939^{36}$, after the war he reconnected with all the leading players of the entire American architectural and social scene: for more than a decade, between 1953 and 1963, he regularly wrote to President Eisenhower too. In 1950 he designed a cabinet for James Plaut, director of the Institute of Contemporary Art in Boston and who would later write the foreword to Ponti's 1954 catalogue "Espressione di Gio Ponti", published in the popular editorial series Aria d'Italia in Italian, English and French ${ }^{37}$. In that occasion, Plaut paid his tribute to Ponti describing him as "a man whose work is still in constant development in a continuity of expression" 38 announcing in the meantime a "definitive exhibition" organized by the Boston Museum and expected to travel through several American cities ${ }^{39}$, illustrating the whole of his activities: 
interiors furnishing, industrial design and architecture, as it was the norm for Italian professionals. The almost exclusive attention to products designed mainly by architects doesn't mean a lack of professional occasion, as will happen during the economic boom. Indeed, all the architects here involved in renewing items quality were at the meantime engaged in the reconstruction of the country, as authors of the new popular "neorealistic" districts and of urban residential buildings intended for the middle and the upper classes ${ }^{40}$.

Returning to the Italy at Work exhibition, and despite the almost kitsch display of the Lambretta scooter and traditional Sicilian chariot which welcomed the visitors (Fig.4) it is not surprising that the selection rather successfully mirrored Ponti's programme for design to blend industry and art, adapted to the already existing map of Italian production districts.

Most of the enterprises and authors presented in the exhibition were the same ones that Ponti normally published in the pages of Domus or were chosen by him or by other curators, for the Triennali or other national or international exhibitions.

Indeed, one of the hallmarks of Ponti's dissemination of the Italian design culture was to emphasize the importance of the role of both the traditional and the modern production districts which were a good representation of a production system still running today. Among the 250 items presented in the travelling exhibition, Azucena (Fig. 5) founded in 1947 by Luigi Caccia Dominioni, Corrado Corradi Dell'Acqua, Ignazio Gardella, Maria Teresa and Franca Tosi, was a typical "design factory", where the architects' projects were created in specific workshops with a high level of handicrafts skills without rejecting the industrial system, the series and the patents as was the case for the Lybra Lamp, patented by Roberto Menghi in $1948^{41}$.

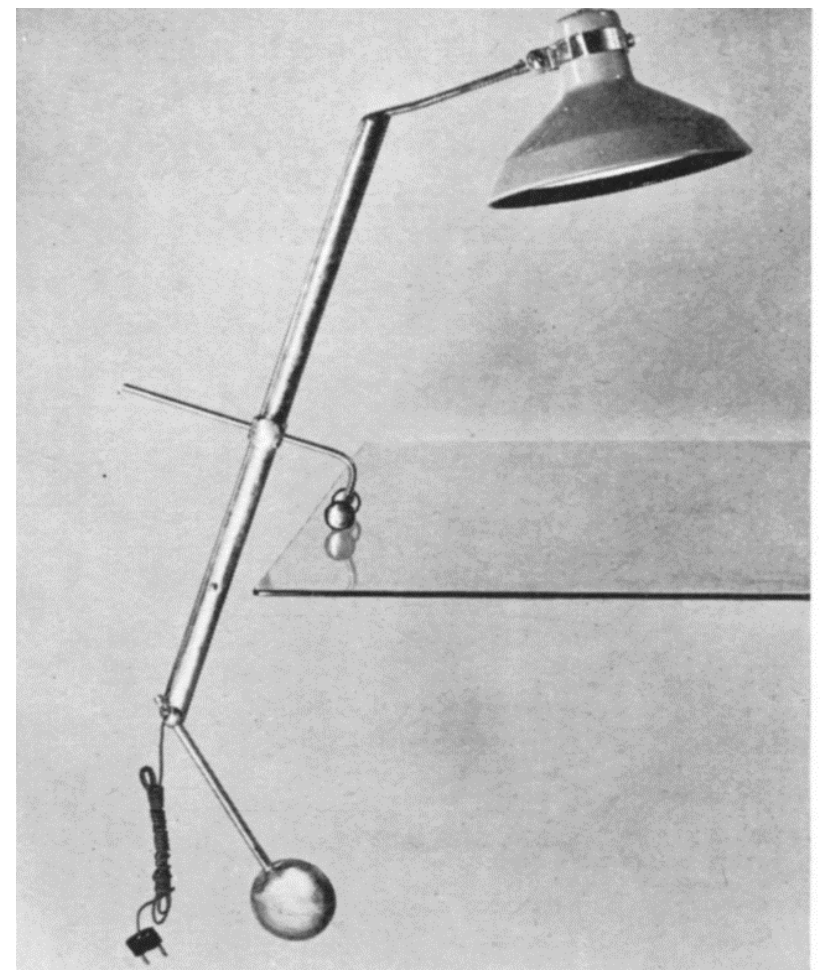

Fig. 5. Self balancing desk lamp, prod. By Azucena, in Italy at work: her Renaissance in Design Today, Rome: 1950, 75 (Central Architecture Library, Politecnico di Torino, Italy). 
Other examples were Arteluce, (founded by Gino Sarfatti in 1939) in a lighting products business that started its industrialisation process in the early 1950s ${ }^{42}$; Richard Ginori (founded in 1890) specialized, as mentioned above, in tableware for different target groups (ceramics and terraglia - pottery- for everyday use and porcelain for the upper classes, all items designed by Ponti or Giovanni Gariboldi) and Fontana Arte (from 1932) specialized in glass manufacture, both in "artistic" and unique pieces and in industrialized ones, for example the Pietro Chiesa flower vase, derived from an industrial, diamond pattern plied window-glass-pain ${ }^{43}$ (Fig. 6.)

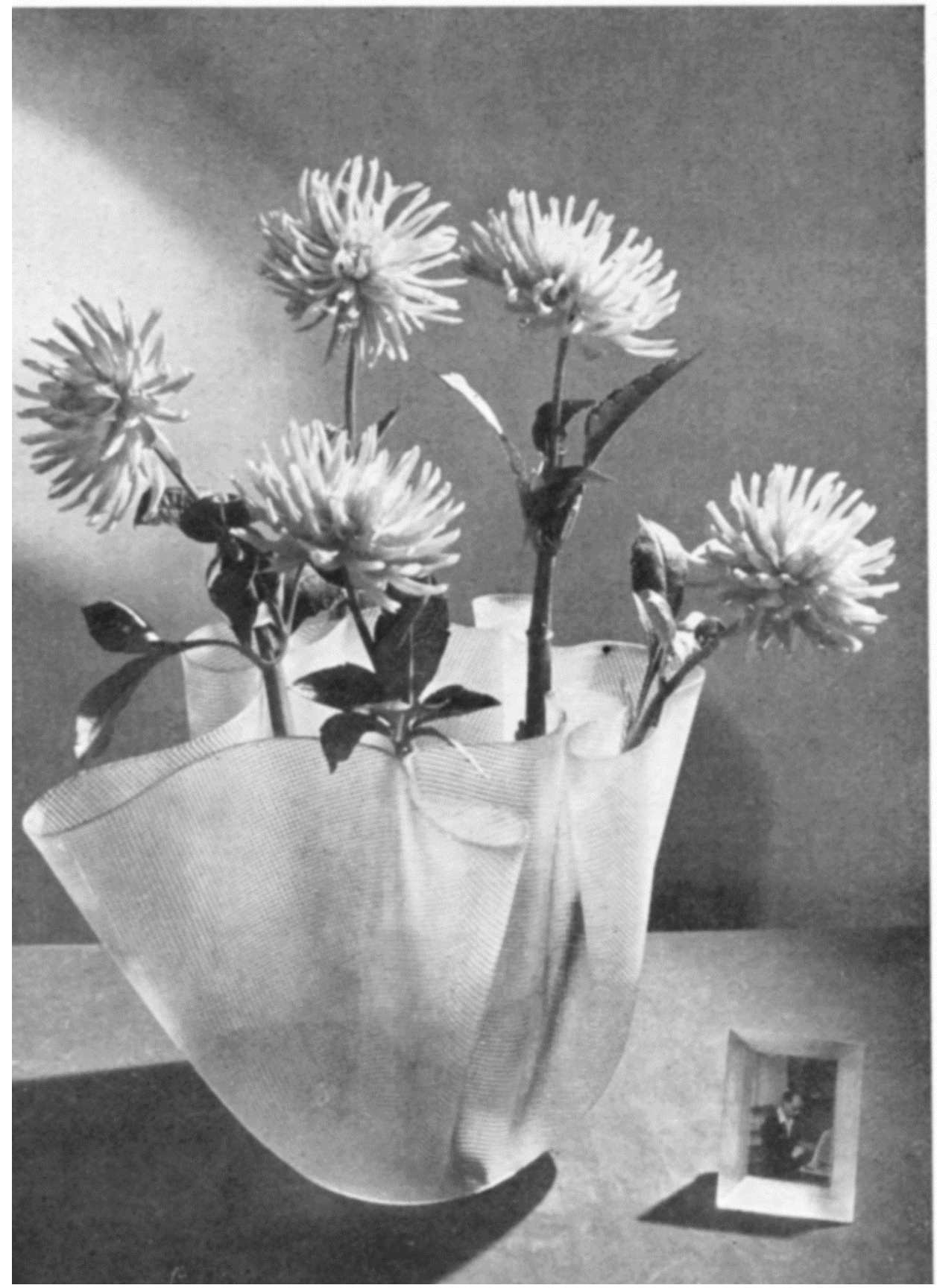

Fig. 6. Vase and photograph frame, prod. By Fontana, des. by Pietro Chiesa, in Italy at work: her Renaissance in Design Today, Rome: 1950, 98. (Central Architecture Library, Politecnico di Torino, Italy. 
Another obsession of Ponti's was well represented by the small series of objects produced in traditional districts in collaboration with artists, for example Lucio Fontana's vases and Aligi Sassu's ceramic tiles or the alabaster tarsia table top by the late Futurist Enrico Prampolini. This desire for cooperation was a huge part of Italian design, both theoretically and practically, climaxing in the $9^{\text {th }}$ Milan Triennial (1951) held under the idea of the "Unity of the Arts" 44 .

The toys exhibited also underlined the two different attitudes: the "straw donkey" 45 encouraged discussion on a prominent contribution of crafts in Italian design while the Lenci dolls were produced in a large company with million-lire turnover and orders from all around the world ${ }^{46}$.

Following these critical marks, the few clearly industrialized items -such as the Lambretta scooter, Olivetti typewriter and calculator and Robbiati coffeemaker- were not that far-removed from other objects perceived as handicrafts and related to their traditional production district, thanks to their unique shapes and the attention in processing special materials.

Talking about this small group of industrial objects, the exhibition curator Meyric Rogers stated that with the due conditions, Italy's universally acknowledged scientific and mechanical skills could be used in industrial design with the Italian sense of form and intellect and that Olivetti's office working system was among the best in the world ${ }^{47}$.

A similar fusion process was represented in the five special environments: the "Mediterranean Terrace" room (focussed on by Domus often before the war ${ }^{48}$ ) by architect and visual artist Luigi Cosenza and ceramist Guido Gambone; the "Dining Room" by Gio Ponti in collaboration with Piero Fornasetti (with inventions that had already been published in Domus such as the fireplace furniture and revolving bar"); the "Transforming Living-Dining Room for a Modest House" by Carlo Mollino, himself an "icon" of the artist/architect hybrid (Fig. 7.); and Roberto Menghi's "Private Chapel" (together with sculptor Giacomo Manzu; Menghi was used to collaborating with artists as can be seen in the Cinema Arlecchino in Milan,1948, with Fontana and Fornasetti ${ }^{50}$ ).

The idea of collaboration between designers, artists and manufacturers (artisans or industrialists) was perhaps Ponti's main goal for most of the 1950s in various occasions ranging from the Triennial to other local exhibitions ${ }^{51}$. Naturally Ponti condemned one of the consequences of Italian design abroad; for example the great sale at Macy's from September $25^{\text {th }} 1951$, which included items and even food and a 36 foot gondola in the central nave of the New York Department Store with a three tonne replica of St Peter's Cathedral ${ }^{52}$.

All of this represented the folkloristic image that Ponti and his group hated and fought against in every possible occasion, claiming the separation between cultural tradition and naiveté, even if this image was one of the major thrusts to commercial success. 

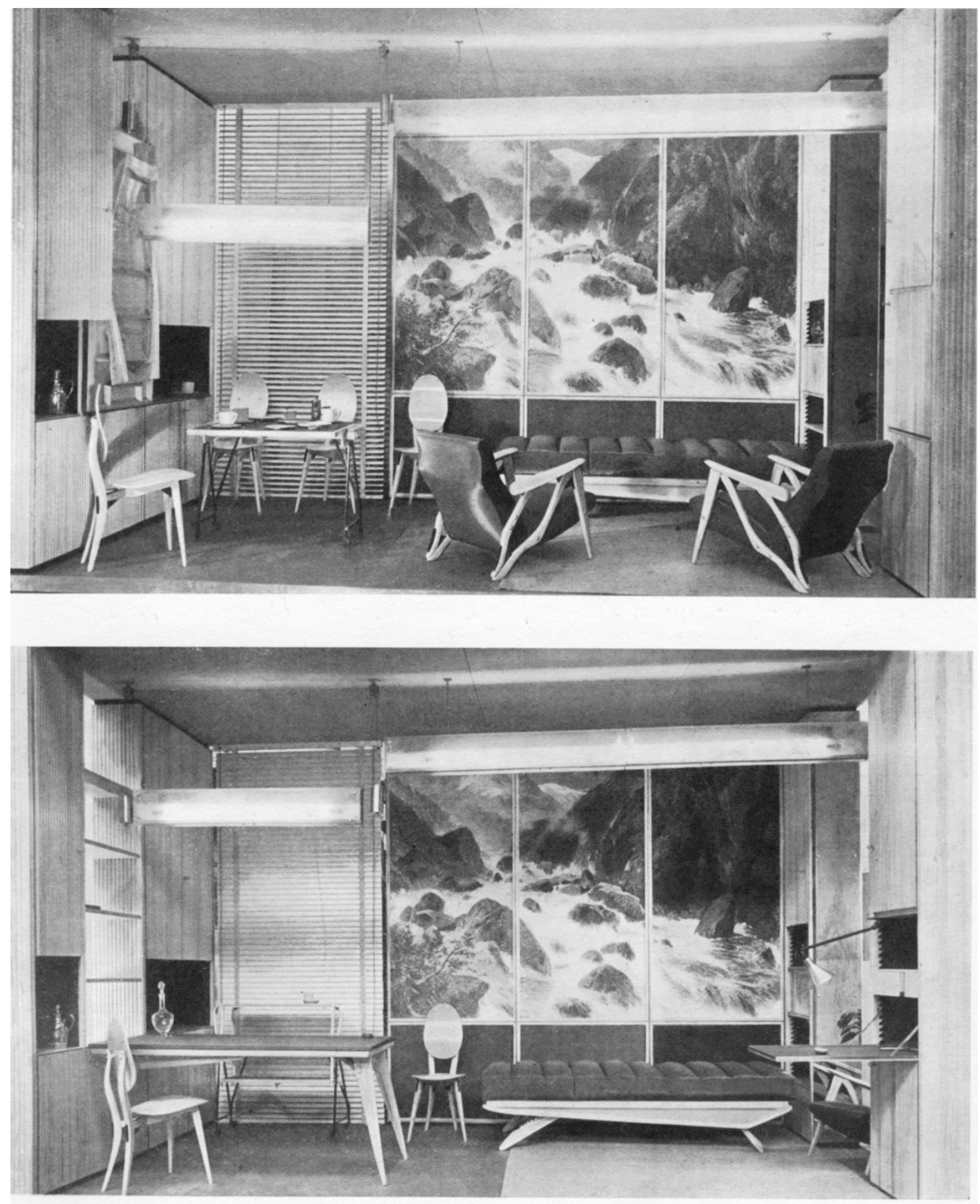

Fig. 7. Living-dining room, prod. By Apelli e Varesio, des. by Carlo Mollino, in Italy at work: her Renaissance in Design Today, Rome: 1950, 59 (Central Architecture Library, Politecnico di Torino, Italy). 
In the long feature that Domus dedicated to the American travelling exhibition, Ponti stated: "The organizers of this exhibition (...) want to interest Americans in "Italian tastes", making them acknowledge it and turning American civilization into a powerful contribution towards an "original" development of these values. They do not intend that Italian production must adapt to American tastes but rather that the American people will fall in love with Italian things" 53 . The article showed an enlarged outline of the last five years of Italian production, re-establishing the balance in favour of the industrial one.

\section{After "Italy at Work": market, magazines and the celebration of Italian Style}

Following Ponti's approach, the American modern-oriented design "Academia" immediately assimilated the "designed" image of Italian products rather than the crafted ones, often improving other aspects of the projects. Anyway even if more focussed on the industrialized items, exhibitions and publications on Italian production within the boundaries of updated research fields, highlighted the artistic approach as typical of Italian designers and industries. The Exhibition 8 Automobiles, at the MoMA (1951) celebrated, among the others "selected for design", the Cisitalia car (1949), by Pinin Farina, in which "the motor and passenger compartment as the wheels are included in a single envelope modelled by swellings and depressions" ${ }^{54}$ following the idea, stated in Johnson's foreword, that cars are "hollow, rolling sculptures" 55 . In other words, this means that the car was "sculptured" instead of built through the addition of volumes such as Mercedes or Talbot were.

Edgar Kauffmann, in another review of the Italy at Work exhibition, stated that architects were driving the process of Italian design and that their tables or chairs had a kind of self-propelled power ${ }^{56}$. In addition, the review published in House and Garden showed a selection of the more industrialized objects ${ }^{57}$.

The December 1952 issue of Interior was dedicated to Italian design ${ }^{58}$ : Roberto Mango, the magazine's co-director, focused on ten authors, including a factory (Olivetti) featuring each one as a demiurge of industrial and interior design, once again pushing the artistic approach. Also the headings used reflected the specificity of the Italian mood: Gio Ponti was "ascetic and sybarite'59, the BBPR firm (Belgiojoso, Banfi, Peressutti and Rogers) were "acrobat"60, Carlo Mollino had a "Baroque spirit"61, Mario Righini (Mango's partner together with Fontana and Fornasetti) made an "harlequinade"62; Marco Zanuso in partnership with two painters used "dramatic inlaid patterns" 63 (Fig. 8.); Angelo Mangiarotti showed the "unusually Italian inventive in devising structures that perform the function of bookshelves" 64 , and so on.

All this seems to mark the end of the road laid by George Nelson, connoisseur of Italian design culture 65 , who wrote about the ability of early postwar Italian architects (faced with a lack of everything) to "unite" tradition and functionalism, inventing and re-inventing new or old solutions without 
submitting to the modernist orthodoxy, probably referring to the Neorealistic, as paiperistic, season 66 . This statement was echoed by the curators of the Italy at work exhibition, who, from a different point of view, mixed authorial, artistic, handcrafted and even anonymous items. Basically, it was the same message Ponti had launched in 1933 with his book/manifesto La casa all'Italiana ${ }^{67}$.

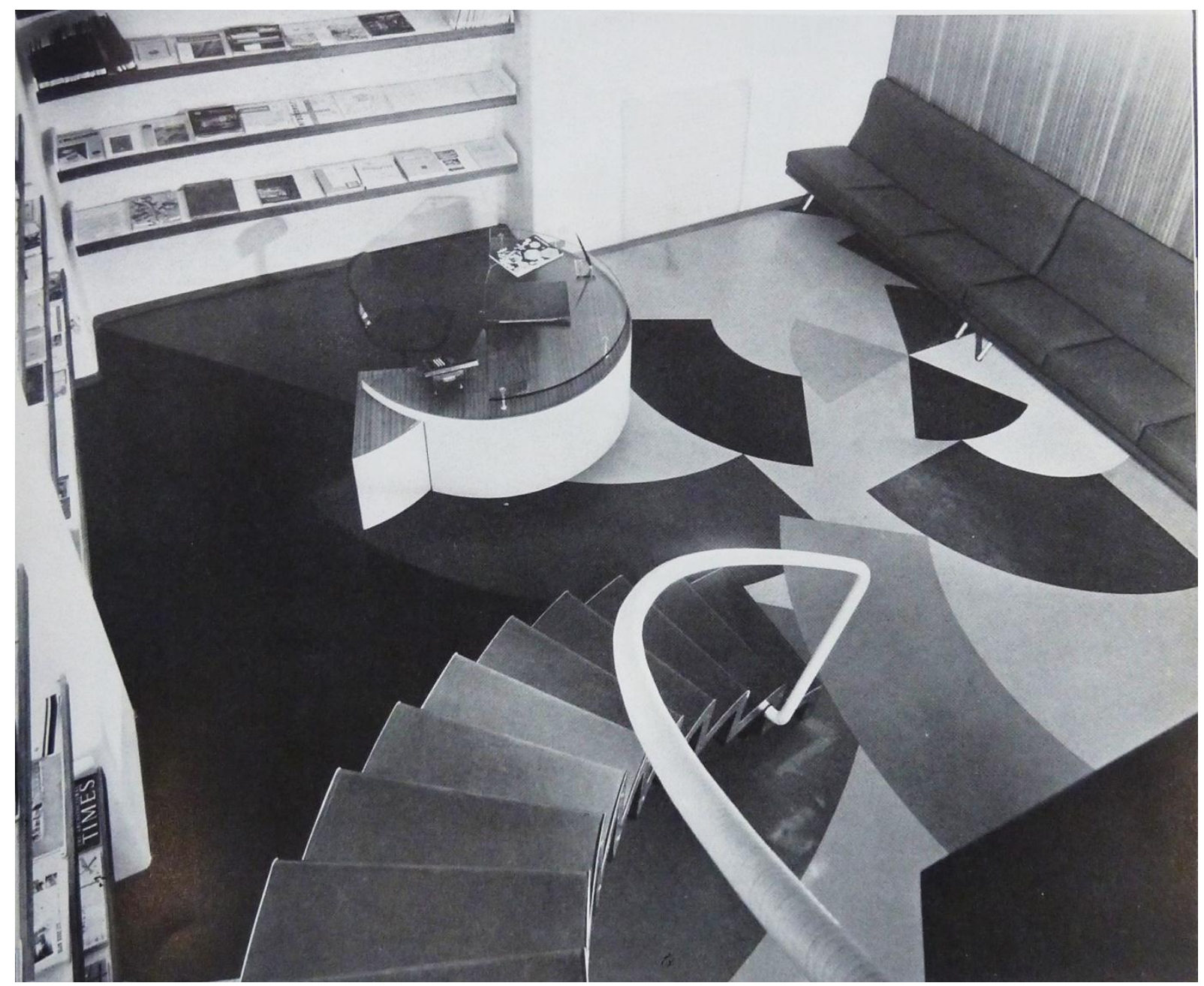

Fig. 8. Milanese interior by Marco Zanuso, “On display without displays”, Interiors CXII, 5

(December 1952): 85

\section{The "design oriented" reactions: industry and shapes}

In 1952, MoMA promoted an exhibition entitled Olivetti: design in Industry, curated by the graphic designer Leo Lionni, who projected the Olivetti showroom in Chicago, while the New York one (1954) was created by the BBPR architecture studio with plastic decorations by artist Costantino Nivola and the lighting system by Venetian blown glass industries Venini ${ }^{68}$. Lionni's exhibition 
and catalogue design ${ }^{69}$ underlined the creativity subtended in Olivetti's mission with graphic solutions that transformed objects into parts of an art installation: silhouettes of sailing ships and tricycles were the background and support of the Lettera 22 and Lexicon typewriters (by Marcello Nizzoli) and a giant pearl collar with drawn typefaces and three styluses tell the evolution of the writing system up to the day of Olivetti's machines (Fig. 9.)
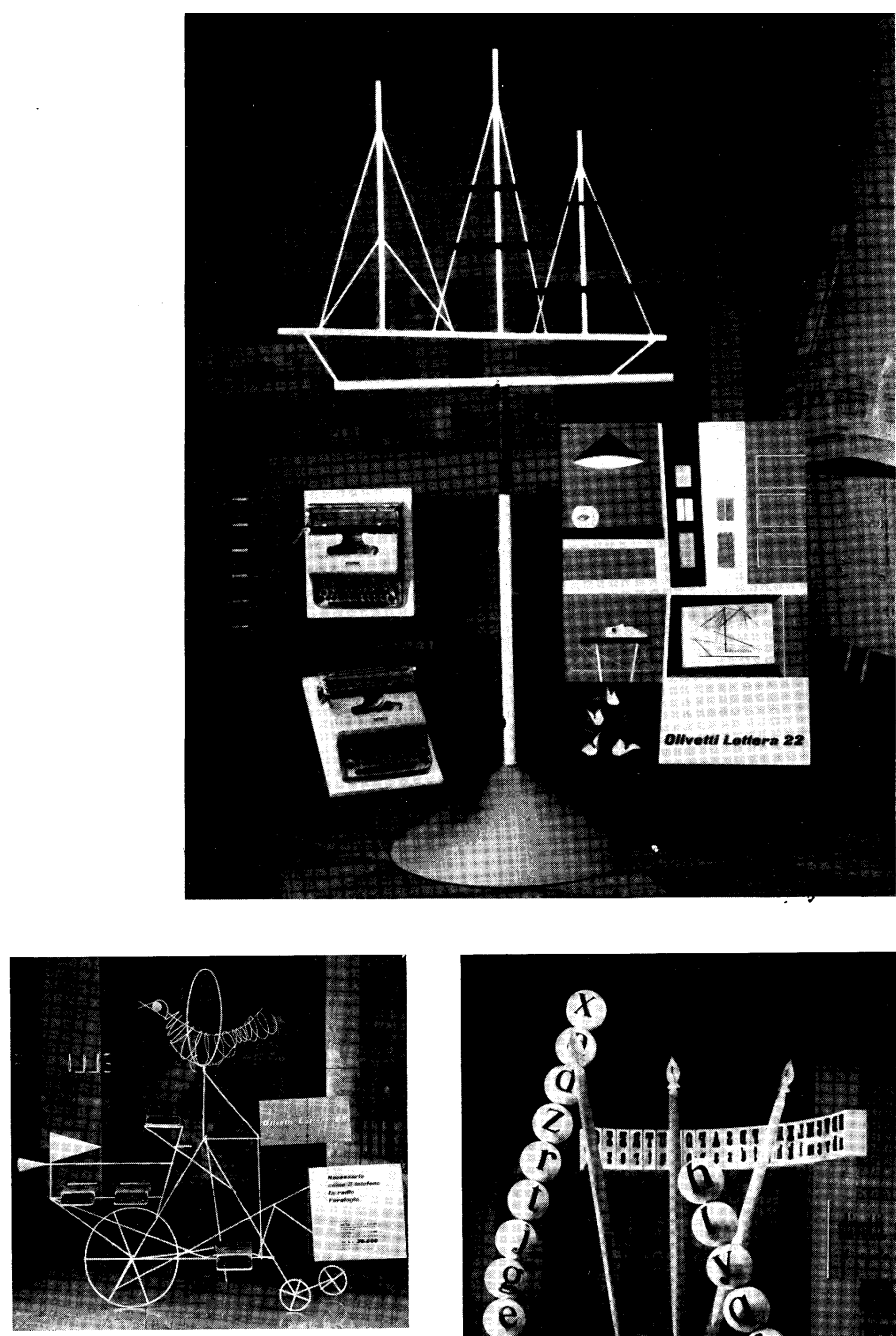

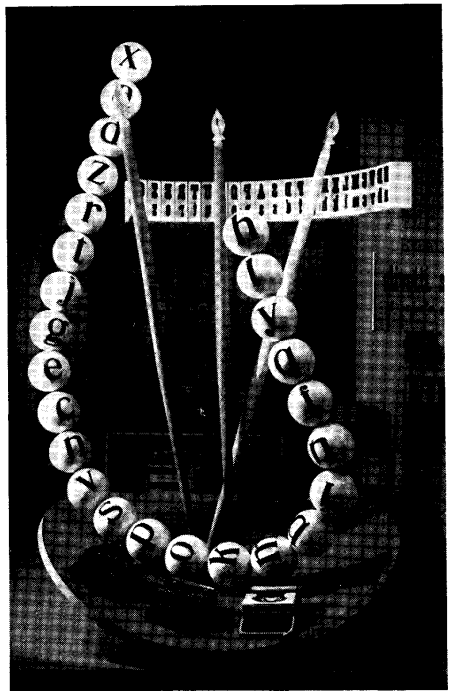

Fig. 9. Display in the exhibition Olivetti design in Industry, MoMA, November 22 to November 30 1952, des. by Leo Lionni, in Museum of Modern Art Bulletin, 1952: 14. 
In 1953, in his opening speech of the first Aspen Design Conference, Nikolaus Pevsner had in turn defined Adriano Olivetti as "an Italian who takes his cultural responsibility seriously and whose buildings are as exemplary as the design of his products" 70 .

The blending of industrial production and art is the hallmark of a curious portfolio commissioned by Fortune in January 1954 entitled Energies of Italy consisting in a series of drawings and paintings by some relevant Italian artists representing "the resurgence of Italian industries"71. The economy-based magazine ${ }^{72}$ chose visual arts to present the growth of the Italian production system to the American public. The selected companies were traditional producers of merchandise such as olive oil, cheese, wine, alabaster or straw hats; innovative ones of products such as sewing machines, calculators, scooters, cars, ships; industrial, including steel, steam energy, turbine pumps; and, finally, companies which blend craftsmanship, art and creativity, in areas such as fashion, blown glass, textiles. "Not only the products of factories and mills, but the works of Italian craftsmen and designers, of Italian painters, sculptors, writers, and movie makers are gaining increasing recognition abroad"73. Artists and illustrators such as Agenore Fabbri (Fig. 10.), Emanuele Luzzati, Giacomo Manzù, already seen in the Italy at work exhibition, Renato Birolli, Bruno Cassinari, Salvatore Fiume drew the products, but the work was primarily meant to represent that of Italians, giving the idea of hard-working and creative people, able to reach, for example, the "Made in Italy stamp of excellence" in fashion production, represented in an extraordinary painting by Massimo Campigli ${ }^{74}$.

The impact of Italian products had been shown also the year before in a kind of press review printed by the Italian Ministry for Foreign Trade, but distributed throughout the US, in which a lot of articles, adverts, reviews of Italian goals were brought together to demonstrate the rapid acceptance of Italian products by American consumers from the beginning of the $1950 \mathrm{~s}^{75}$ (Fig. 11.): echoes of movies, couture, leather gloves, fabrics, furnishings but also fairs in both countries or cruise companies gathered from every kind of magazine and journal, from Harper's Bazaar to The New York Times, New York Herald, Vogue, Tribune, Life and a lot of other publications across the country, shaping what we call today "Italian Style": "Beauty, good taste and usefulness are your first considerations when you choose something of Italy's artistic production", the preface boldly stated, continuing "It is a living force and is blossoming forth once again in a new Renaissance"76, celebrating the primacy of Italy over other European countries: "Italian Look Prettier than the Paris Look" said an anonymous journalist regarding the Fontana Sisters' defilé in Hollywood ${ }^{77}$. 


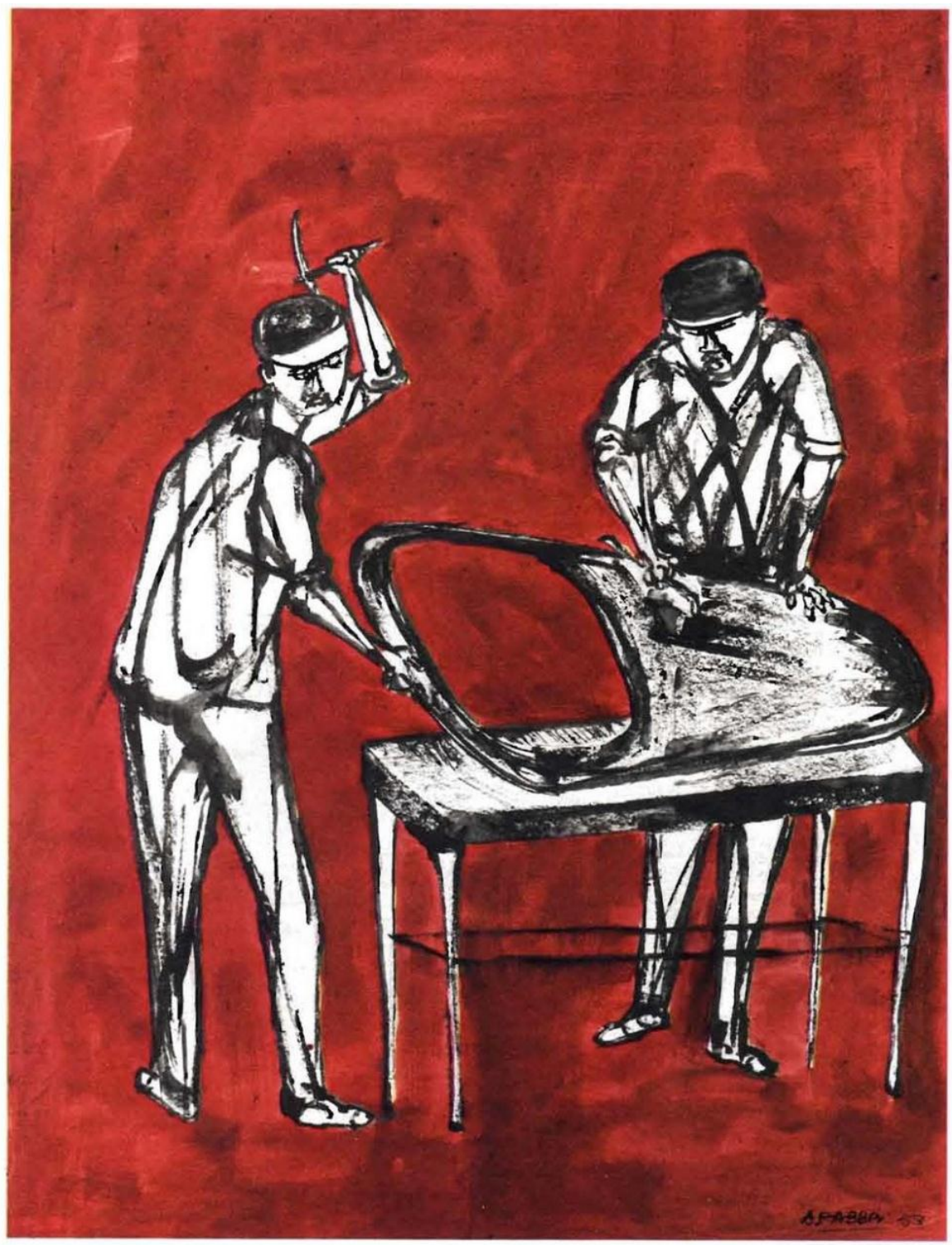
The Arnolt car, an aristocratic body on an English (MG) chassis, body on an Engish (MG) chassis, and it was originally built on the initiative of S. H. Arnolt of Warsaw, Indiana. Arnolt, manufacturer of furniture tubing, marine parts, etc., and a distributor of foreign cars, persuaded MG that a larger body phoult for the U.S. market. Arnolt and Bertone, body designer, together worked out the prototype of the car with the bigger body. About ten cars a month are being produced at the Bertone factory in Turin (the painting above was made there by Agenore Fabbri) ; the first cars sent to the U.S. were quickly sold. Prices here are $\$ 3,585$ for the closed car, $\$ 3,735$ for the convertible. The car will be displayed at the New York Automobile Show this winter

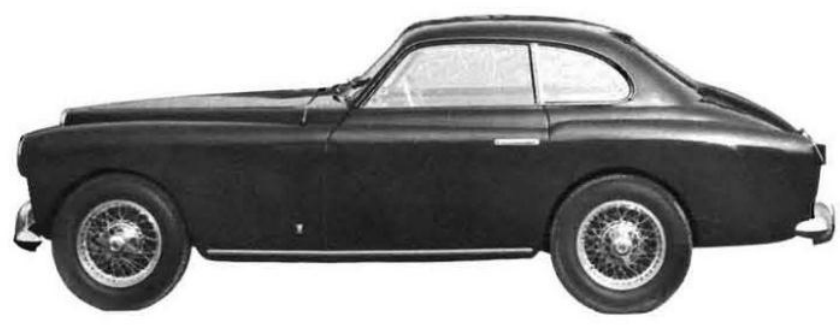

FORTUNE Januery 10S4 103

Fig. 10. Painting by Agenore Fabbri representing the Bertone car factory, Turin, in "Energies of Italy", Fortune, January 1954, 103. 

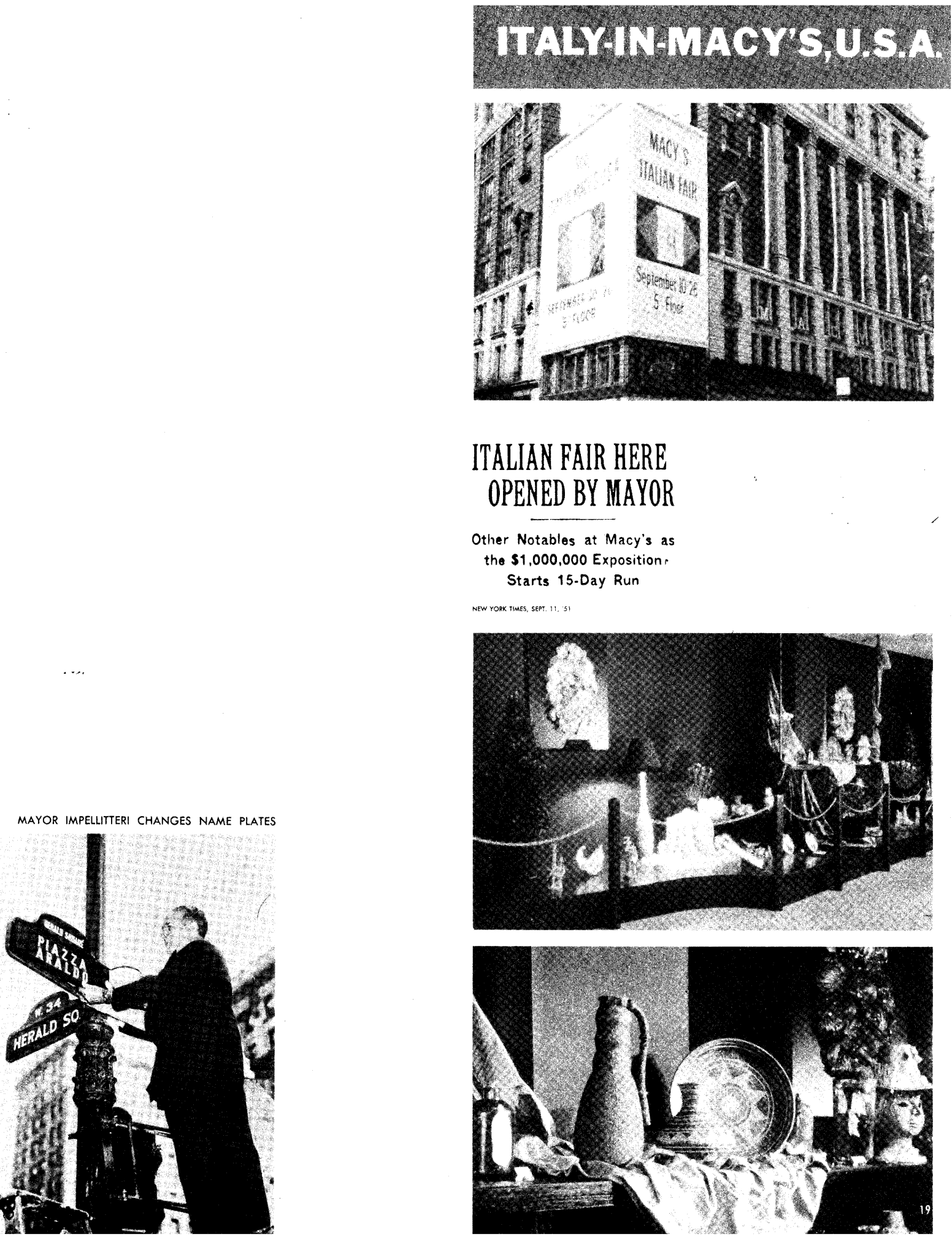

\section{ITALIAN FAIR HERE OPENED BY MAYOR}
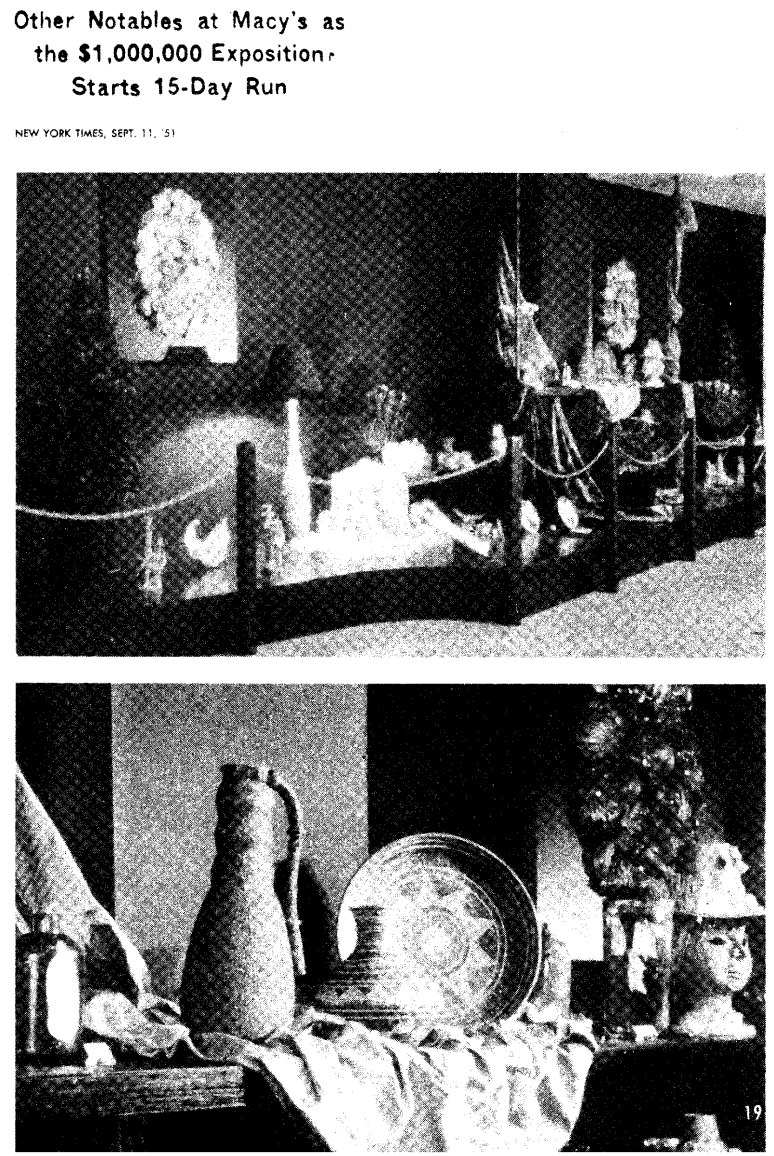

Fig. 11. Page from the press-collection Italy Creates, pamphlet prepared by the Comercial Attache of the Italian Consulate General in New York, Rome 1952, 19. 
Esquire also paid a tribute to Italy, in the holiday edition of 1953. The Italian Fair portfolio included an article by Robert Ruark who said about Rome "today truly once more the capital of the world, old beyond the ages in her treasured preservation of the past, and as sleekly modern as a jet plane in her practice of lush modernity"78. To demonstrate this, Esquire's scouts founded and published mechanical devices ranging "from an impersonal machine to a possession of an original charm": Ferrari model 212, Olivetti Lettera 22, Lambretta scooter and Beretta shotgun represent "Ever Creative Italy"79; men's deluxe clothing and sports-wear, the unavoidable pieces of furniture and tableware by Gio Ponti and Carlo Mollino - already seen in Italy at Work - all the way down to the antipastos and Chianti wine were "surely a promise that Italy is once again herself -vital, patient, prolific, and ready to blend flavour with spice for the perfect result" 80 . What the columnist and, more generally, the US popular press wanted to spread was the idea of the ability of the whole Italian people to resurge again and again, reaching increasing levels of excellence to distribute throughout the American market.

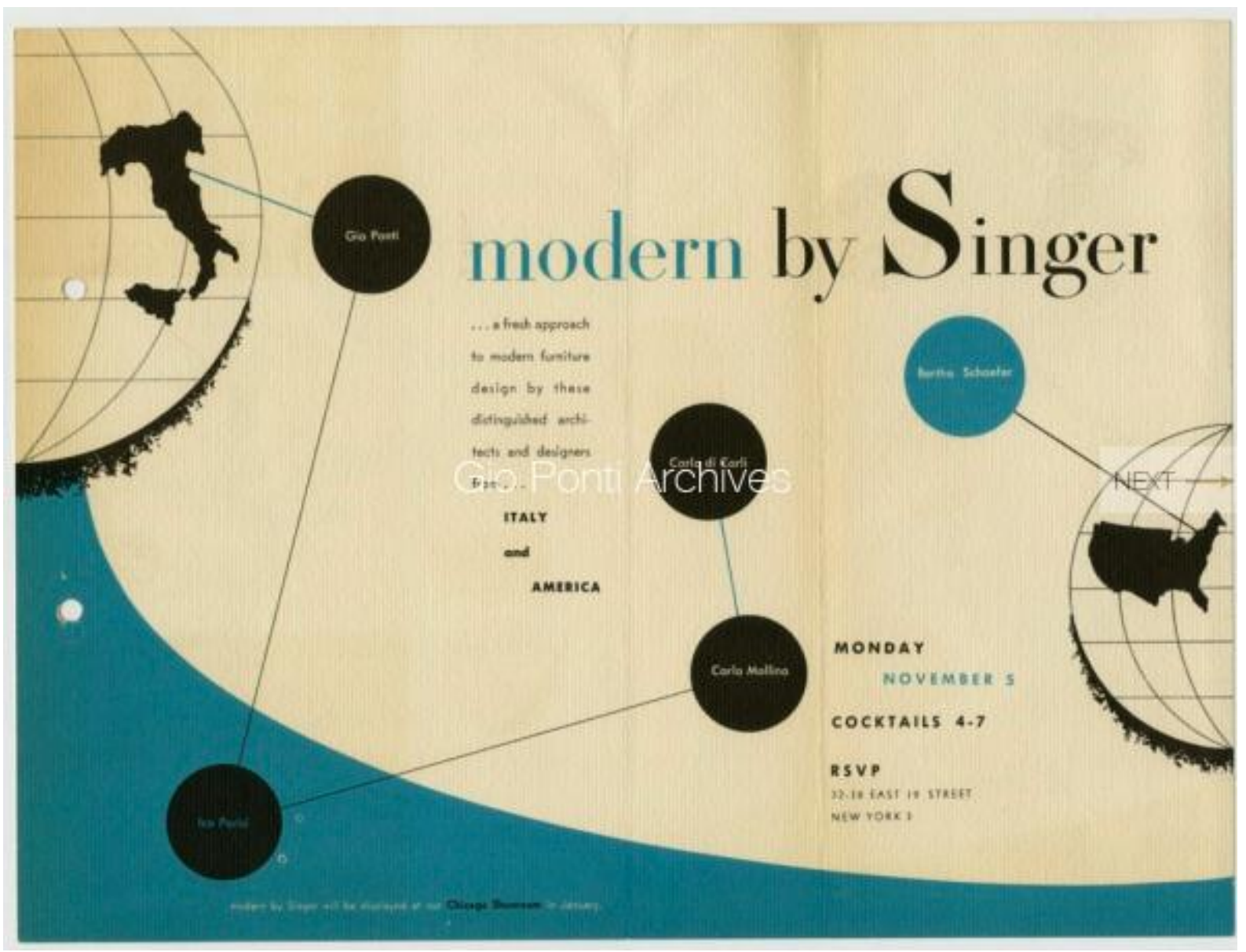

Fig. 12. Announcement of the opening at the Singer \& Sons showroom "Modern by Singer", Gio Ponti Archives, Milan. 
Indeed American furniture production certainly looked towards the Italian style mirroring Ponti's proposals: in 1952, a number of pieces of furniture by the Italian Gio Ponti, Carlo Mollino, Ico Parisi, Carlo De Carli and the American Bertha Shaefer were presented in the Singer \& Sons showroom in New York with the slogan: "a fresh approach to modern furniture design by these distinguished architects and designers from Italy and America" 81 (Fig. 12.)

Most of the furniture was a re-elaboration of Italian products which Ponti and the others were developing at the time: the Ponti's Leggera chair, then Superleggera (1957), was in production for Cassina and his wall systems were elaborated and produced as unique items for the Triennial exhibition in 1951 and $1954^{82}$.

During the same period, Altamira company (in partnership with Ponti since 1939, as previously Knoll had been with Albini), edited a catalogue of Italian furniture, glassware, lamps and accessories ${ }^{83}$. Ponti illustrated several of these objects in different articles in Domus, emphasizing the "American Interest in Italy" 84 and linking older sources with the so-called "New Italian Renaissance", a turn of phrase coined by American critics and intellectuals covering architecture, literature, cinema and, of course, design. He insisted that it was a "continuity", founded before the Second World War and the American intervention, as the Triennial exhibitions had previously clearly shown. With this in mind, he also identified Giuseppe Pagano and Edoardo Persico, the former Casabella directors who disappeared before the last Renaissance -and war- (and perhaps unconscious protagonists of modern industrial design) as maitres ${ }^{85}$. Ponti's choices in demonstrating the range of the Italian project in the US varied from modular furniture such as wall accessories or the "finestra attrezzata" (equipped window) by Ponti himself, produced by Altamira (Figs. 13-14) to industrialized furniture (for example, the Parisi Cono chair or De Carli's demountable chair produced by Cassina at the same time), to the fruits of the collaboration between architects and artists, such as the tables by Ponti and Paolo De Poli or by Parisi and the abstractionist Como painter Mario Radice. What he wanted to demonstrate was that "what characterises Italian identity in these pieces of furniture is not an Italian style, nor the rigor of a line or of an Italian school, but is rather the simultaneous presence of a wide variety of Italian creative natures collected in order of their combination of affinities and activities of creative quality in diversity" 86 . This and other statements seems to match his own vision with the American one, building somehow a shared identity for Italian design and driving both, a cultural and commercial success. 

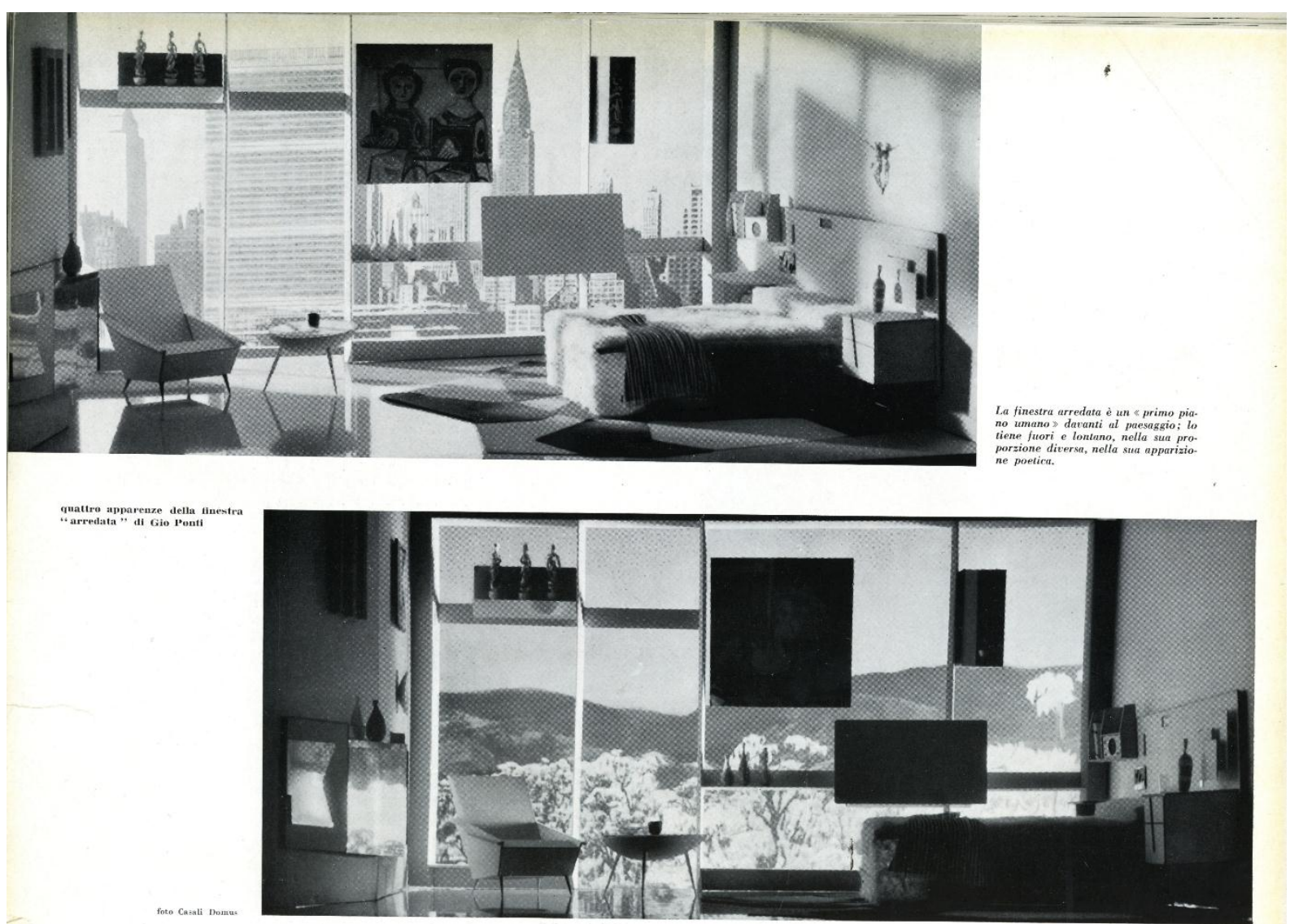

Fig. 13. The Finestra arredata by Gio Ponti for Altamira Inc., in Domus 298 (september 1954): 19. Photo Casali.

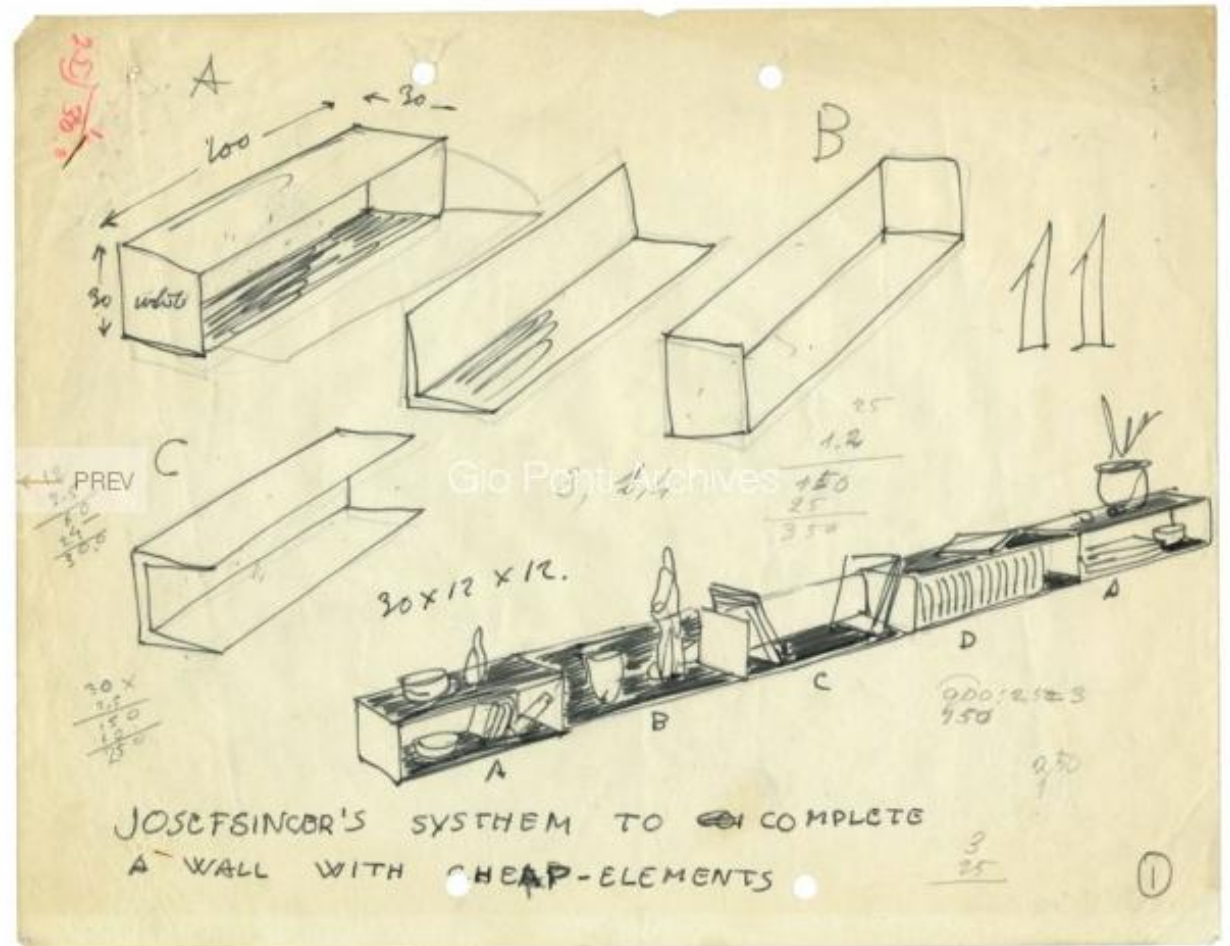

Fig. 14. Gio Ponti, Wall System for Singer \& Sons, ar. 1952, Gio Ponti Archives 
Indeed, another author who enjoyed great commercial success in US was Roberto Mango, a devoted admirer of Buckminster Fuller, whose geodesic dome he brought to the $10^{\text {th }}$ Milan Triennial in 1954, in which Altamira production was also displayed, and whose studies on tenso-structures he discussed during an apprenticeship at the Fuller Research Foundation (1951). He was in America as a "special student" with a Fellowship by courtesy from Princeton from 1949, following Bruno Zevi's interests in Organic Architecture and studies on prefabricated buildings. After participating in the MoMA competition for Lamp design in $1950^{87}$, he became a correspondent for Domus -thereby moving under the protection of Ponti - and art director of Interiors in 1951-1953. He was appointed Instructor of Advanced Interior Design at the Whitman School of Interior Decoration, New York in 1950-51. Allan Gould Design Inc, New York commissioned his company (in order to launch them onto the US market) more than 1000 of his Sunflower chairs (Fig 15.) an example of a blending of artisan skills (midollino) and industrial techniques (iron rod) partially produced in Italy for R.M. Inc. by local craftsmen. The direct and indirect advertising of this chair focused on its handcrafted "Italianness", even if the original pattern was improved in a more industrial way with a patent in $1953^{88}$, once again mixing design, technique and the Mediterranean $\operatorname{mood}^{89}$.

Mango's experience with the midollino and its manufacturing was also taken into account by Maurizio Tempestini, another Italian architect who worked for some years in the US and designed a strikingly large number of gardens and interior furniture for Salterini Industries New York, which were advertised and reviewed in all architecture and popular magazines ${ }^{90}$.

American perception and commercial interest, together with Ponti and his peers' description, drew Italian production - both artistic and industrial - quite a way from the original intentions of the American political programme for Italian craftsmanship revival following Rogers' text in the Italy at Work catalogue as "The sight of the unity of Arts of Design"91. In this fluctuation between tradition and modernity, the MoMA exhibitions mainly promoted the latter, of course, thanks to contributions by some sincere admirers of the Italian modern style, such as Ada Louise Huxtable, who was in Italy with a Fulbright fellowship in 1950-1951 and curated an exhibition entitled The Modern Movement in Italy: Architecture and Design which travelled throughout the US and Canada ${ }^{92}$. As somebody who had been really involved in the post-war period, and even quoting as usual the omnipresent Renaissance and the power of creativity, she looked at Italian design in all its components and reached an accurate and precise definition: "Supports are treated almost independently, contrasted with sculptural forms in wood, metal or marble. This juxtaposition of the staccato straight line with the flowing curved line, of the geometric shape with the free form, is a specific characteristic of Italian design"93. 


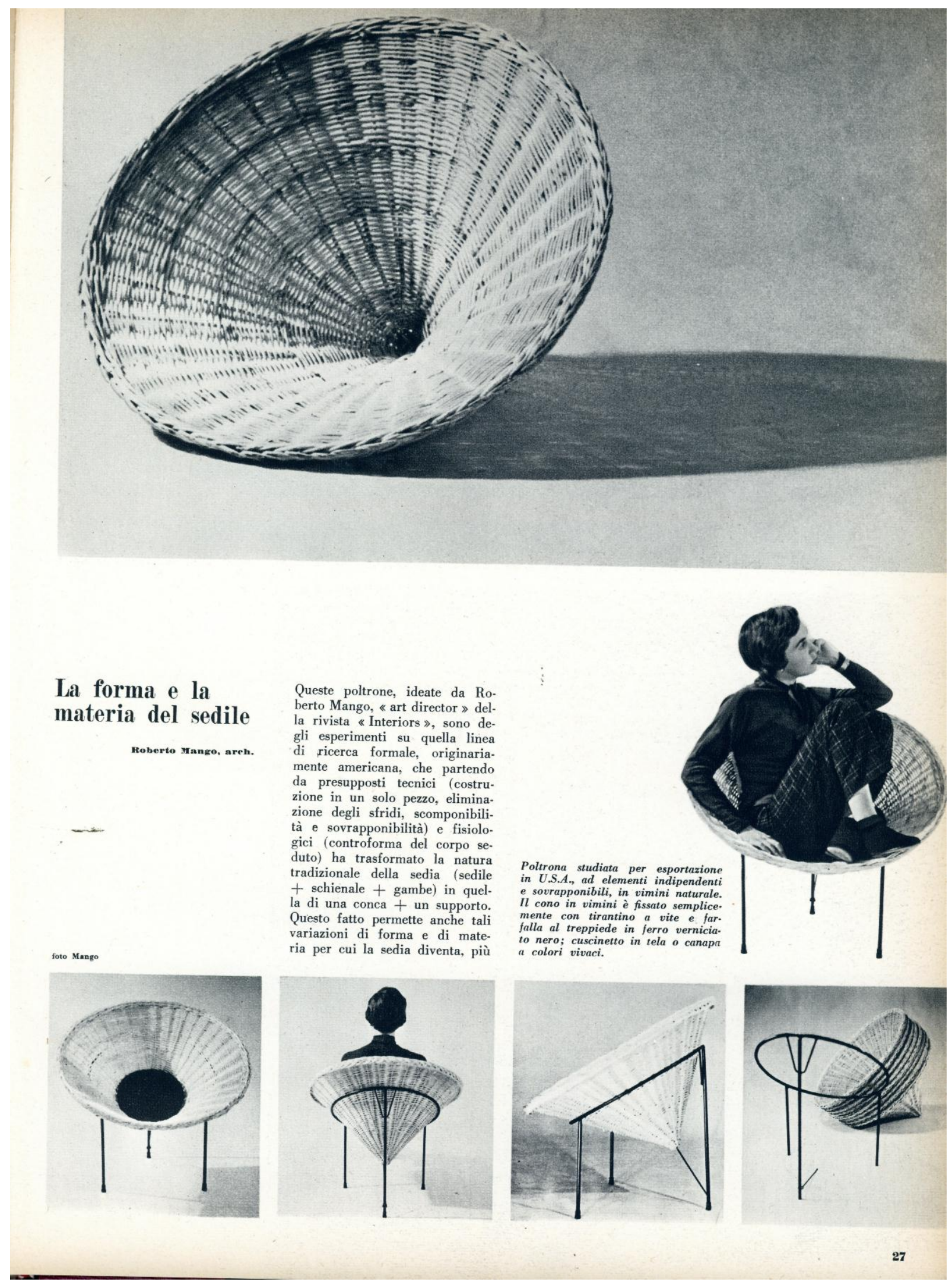

Fig. 15. Sunflower chair, by Roberto Mango, distribute in US by Allan Gould Inc., Domus 285, (August 1953): 27 


\section{Conclusions}

Summing up all of the contributions, the impression we can receive is that the platonic idea of Italian craftsmanship, well epitomized by Gio Ponti himself defining his Superleggera chair "a chair-chair, modestly without adjectives"94, and the use of traditional artisan skills could both be retooled in an original industrial way, mirroring the role of Ponti as a "generous multiplier of their culture" 95 . This outline mirrors in turn the spread of Italian design driven both by the American market and by the intellectual community. Indeed, from the 1920 s, and undergoing a strong development and improvement period in the 1950s (thanks to American financing and propaganda too), these two approaches allowed in Italy the definition of a network of craft or small-scale industries and companies that would become the very same Italian industrial design production system that is still a mark of excellence today. Furthermore it does not compete with the new American design much more oriented towards industrialization and large numbers ${ }^{96}$ and fits well with its promotion that Americans continue until the eighties ${ }^{97}$. Promotion that was in short well summarized in an edition of Life Magazine from 1961 in which new architecture built for the Italian Union Centenary celebrations, the first skyscrapers, fast trains and advanced concrete buildings, was used as the set for dresses created by fashion designers representing a "Dramatic Decade of Italian Style"98 (Fig. 16.)

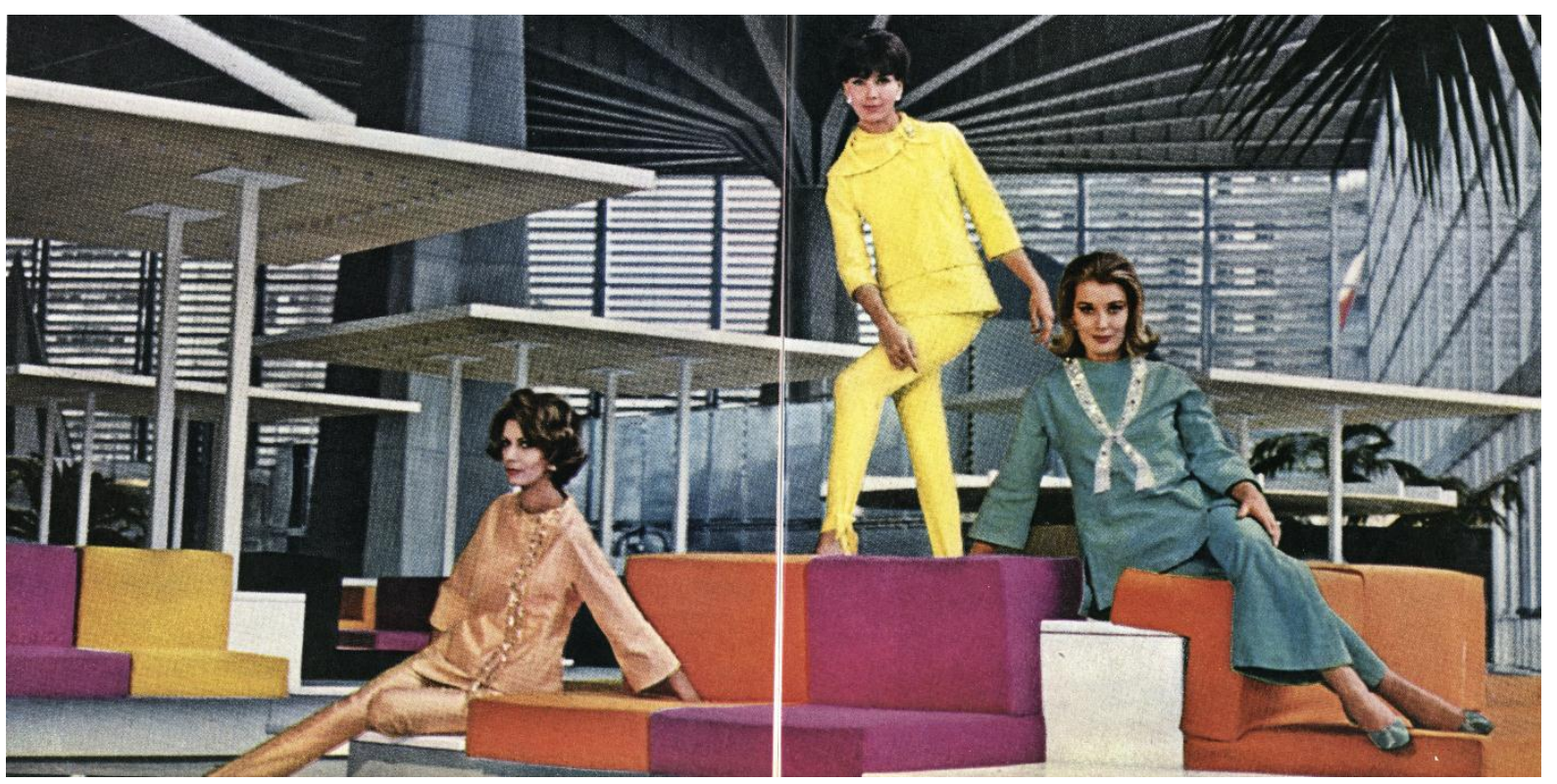

Fig. 18. Three variations on evening-slack outfits by Irene Galitzine, displayed in the refreshment centre of the "Palazzo del Lavoro" exhibition building, Torino, 1961 (arch. Pier Luigi Nervi, furn. Ettore Sottsass jr., ph., Mark Kaufmann for Life), Life, December 1, 1961: 76-77. 


\title{
NOTES
}

\author{
${ }^{1}$ SHERER, Daniel, "Ponti a New York", in Espressioni di Gio Ponti, G. Celant, ed., Milan, Electa, 2011, pp. 56, \\ 35-43. \\ ${ }^{2}$ DELLAPIANA, Elena, Il Design della ceramica in Italia 1850-2000, Milan, Electa, 2010, pp. 43-65. \\ ${ }^{3}$ Ibídem pp. 100-109. \\ ${ }^{4}$ FISHER, Julia C., More than mere playthings: the Minor Arts of Italy, Cambridge, Cambridge Scholar
} Publishing, 2016, pp. 99-123.

${ }^{5}$ For example, Giuseppe Pagano and others designed for the Columbus incorporated in Milan several pieces of furniture in tubular steel: PANSERA, Anty, BASSI, Alberto and OCLEPPO, Tiziana, eds., Flessibili splendori. I mobili in tubolare metallico: il caso Columbus, Milan, Electa, 1998.

${ }^{6}$ For example, Stile magazine, which Ponti edited from 1941 to 1947, and in which he gathered together samples of all visual arts, literature, music; MARTIGNONI, Massimo, Gio Ponti. Gli anni di Stile, Milan, Abitare Segesta, 2002; moreover the Fascism promoted a politic to improve craftsmanship setting up associations like ENAPI (Ente Nazionale Artigianato Piccole Industrie, 1925) and several dedicated exhibitions, DELLAPIANA, Elena, "De Poli e le arti applicate e decorative in Italia", in A. BASSI, S. MAFFIOLETTI eds., Paolo De Poli artigiano, imprenditore e designer, Padova, Il Poligrafo, 2017, pp. 184-195.

${ }^{7}$ This was the only example of Italian architecture among "the poets of steel" as Alfred Barr Jr. stated in the foreword of the book related to the exhibition and published in the meantime of the catalogue, HITCHCOCK, Henry-Russel and JOHNSON, Philip, The International Style, New York-London, Norton \& Co, 1932; the Electric House was given the caption: "The same unit of measurement in windows and railings produces a subsidiary rhythm", p. 145.

${ }^{8}$ There were different versions of this exhibition with and within the modern section; the most impressive paintings were masterpieces by Botticelli, Michelangelo, Raphael and other Italian Renaissance masters (28 pieces in total); BEDARIDA Raffaele, “Operation Renaissance: Italian Art at MoMA, 1940-1949”, Oxford Art Journal, 35.2 (2012), pp. 147-169; MoMA Press Release Archives, 1959_0132_104J.

${ }^{9}$ CARPENTER, Wava Jean, Designing Freedom and Prosperity: The Emergence of Italian Design in Post-war America , Master's thesis MA program in the History of the Decorative Arts and Design Cooper-Hewitt, National Design Museum, Smithsonian Institution and Parsons The New School for Design 2006.

${ }^{10}$ RAGGHIANTI, Carlo Ludovico, Preface to Handicraft as a Fine Art in Italy, Florence, CADMA, 1947.

${ }^{11}$ Milano com'è. La cultura nelle sue strutture dal 1945 a oggi. Inchiesta, Milan, Feltrinelli, 1962, pp. 740-743; 831-832; 955-956.

12 "Memo: What is Handicraft Development Inc.?" (1945), Max Ascoli Collection, Howard Gotlieb Archival Research Center, Boston University, Box 201, Folder 4.

${ }^{13}$ PESANDO, Annalisa B., Opera vigorosa per il gusto artistico nelle nostre industrie, Milan, Franco Angeli, 2006; somehow as happened in England and Scotland, in Italy the "crafting" and "modernity" dialectic, was supported by the local artistic traditions; the choice of Middle Ages -Gothic or Romanesque- Renaissance or Arabian sources depended from the origins of the authors; PATETTA, Luciano, Architettura dell'Eclettismo. Fonti, teorie, modelli. 1750-1900, Milan, Città Studi, 1991; DELLAPIANA, Elena, "Camillo Boito (18361914)”, in A. RESTUCCI, ed., Storia dell'architettura italiana L'Ottocento, Milan, Electa, 2005, pp. 590-605.

${ }^{14}$ SOBY, James Thrall and BARR, Alfred, J. Jr., eds., Twentieth-Century Italian Art, New York, The Museum of Modern Art, 1949.

15 The essay "Painting and Sculpture since 1920 " is by James Thrall Soby, one of the curators of the MoMA exhibition, specialized in Surrealism, ibid. 25-33.

${ }^{16}$ SOBY and BARR Jr., eds., Twentieth-Century, cit. p. 5; BEDARIDA, “Operation Renaissance”, cit. pp. 154156.

${ }^{17}$ PONTI, Gio, "Scambio di lettere", in Domus 237, (1949 June), p. XII.

${ }^{18}$ PONTI, Gio, "La scelta del Museum of Modern Art”, in Domus 234, (1949 March), p. 50. 
${ }^{19}$ GORDON KANTOR, Sybil, Alfred H. Barr Jr. and the intellectual Origins of the MoMA, Boston, MIT, 2002.

${ }^{20}$ BEDARIDA, Raffaele, "Export/Import: The Promotion of Contemporary Italian Art in the United States, 1935-1969", in CUNY Academic Works (2016). Cfr. http://academicworks.cuny.edu/gc_etds/73. Last visit 10/11/2017.

${ }^{21}$ PEPALL, Rosalin, "Good Design is Good Business": Promoting Post-war Italian Design in America", in G. BOSONI, ed., Il Modo Italiano - Italian Design and Avant-garde in the $20^{\text {th }}$ Century, Milan, Skira, 2006, pp. 7889.

${ }^{22}$ ROGERS, Ernesto Nathan, "Milan: Design Renaissance", in Vogue, September 15, 1949, 152-157; ph. by Irving Penn; I thank Giampiero Bosoni for pointing me this article; BOSONI, Giampiero,"Milan: Design Renaissance": prophecy of "the new domestic landscape" in Italy", New York, MET, forthcoming.

${ }^{23}$ SCRIVANO, Paolo, Building Transatlantic Italy. Architectural Dialogues with post-war America, Burlington, Ashgate 2013.

${ }^{24}$ In these projects, we can talk about a neo-realistic approach to architecture, as was the case in literature, visual art, cinema and theatre; for an outlook on the design culture, SABATINO, Michelangelo, Pride in Modesty: Modernist Architecture and the Vernacular Tradition in Italy, Toronto, Buffalo, London, University of Toronto Press, 2010.

${ }^{25}$ New York Times, August 2, 1945.

${ }^{26}$ On this "fair" SPARKE, Penny, "The Straw Donkey: Tourist Kitsch or proto-design? Craft and Design in Italy, 1945-1960", in Journal of Design History, 11-1 (1998), pp. 59-78; ROSSI, Catharine, Crafting Design in Italy. From post-war to post-modernism, Manchester, Manchester UP, 2015, pp. 10-52, SPARKE, Penny, "Industrial Design or Industrial Aesthetics? American Influence on the Emergence of the Italian Modern Design Movement, 1948-58", in C. DUGGAN and C. WAGSTAFF eds., Italy in the Cold War. Politics, Culture \& Society 1948-58, Oxford, Berg, 1995, pp. 159-166.

${ }^{27}$ SCRIVANO, The trasatlantic, cit., pp. 42; 73; Angelo Mangiarotti was at the Institute of Design of Chicago in 1953-54: SANTI, Carlo, "Institute of Design di Chicago. Angelo Mangiarotti: esperienze di insegnamento", in Stile industria, 4 (April 1955), pp. 7-9.

${ }^{28}$ LIONNI, Leo, between Worlds: the Autobiography of Leo Lionni, New York, Knopf, 1997.

${ }^{29}$ His presence in New York, Madison Street 12, is confirmed in the "address book" in the June 1949 edition of Domus (n. 237).

30 “Architettura Contemporanea negli Stati Uniti 1947-1949" was an exhibition promoted in 1949 by the American Institute of Architects, SCRIVANO, The transatlantic, cit. p. 38.

${ }^{31}$ RUDOFSKY, Bernard, "Fifty Pages of Post-war Furniture and Interiors from Italy", in Interiors, 12, (July 1948), pp. 70-120; CASCIATO, Maristella, "Between Craftmanship and Design, "Italy at Work", in J.M. POZO MUNICO, J. MARTINEZ GONZÀLEZ, eds., La arquitectura norteamericana motor y espejo de la arquitectura espanola, Pamplona, Servicio Publicaciones Etsa, 2006, pp. 9-18; on Rudofsky, BOCCO GUARNERI, Andrea, Bernard Rudofsky: A Humane Designer, Wien, Springer-Verlag, 2003; DELLAPIANA, Elena, "Case e sandali: Bernard Rudofsky dalle isole del Mediterraneo al mito dell'anonimo", in A. MAGLIO, F. MANGONE, A. PIZZA eds., Immaginare il Mediterraneo. Architettura arti fotografia, Napoli, ArtStudioPaparo, 2017, pp. 205214.

32 NELSON, George, "Blessed Are the Poor," in Contract Interiors 107 (July 1948), pp. 71-86. Nelson's statement echoes an influential article published by the art historian Lionello Venturi in Casabella at the beginning of the Thirties focused on the "proud of modesty" as a program for Italian architecture; this topic became pivotal in the post war years, VENTURI, Lionello, "Per la nuova architettura", in Casabella, VI, 1 (January 1933), pp. 2-3; thanks to Dario Scodeller who reported me this relationship.

${ }^{33}$ Gio Ponti Archives, Milan, Correspondences. We can find a large number of contact with American industrialists, intellectuals and officials, such as Arnoscht Ernesta (American Export Lines) 1950/51; Arthur Inc. 1950/57; Bayley R.W. (Arthur Sanderson \& Sons Ltd.) 1953/60; Pietro Belluschi 1959; Thomas Buechner (Glass Museum, N.Y.) 1959; Builder - magazine 1956/57; John Burchard (dean M.I.T.) 1959-1960-1961-19631969; Alexander Calder 1959/68; Calvert Distillers Ltd. 1954/55; Betty Campbell (Cement \& Concrete, magazine) 1956/57; Humphrey Carver 1954/55; J.W Cohn (Home Furnishings Daily) 1959; Calvert Competition- Mc Gill University 1954/55; New York Conference 1954/61-1962/66; American Consulate in Milan 1950/54; John Donald Cordwell 1954/55; Lucien Cowan (Crane Ltd.) 1953/66; James Craig 1954/55; Jeanne Davern (Architectural Record) 1959-1962-1971-1974-1978/79-1962/67-1970-1962/63-1968/73- 1976- 
1977; Mario De Matthaeis (Cultural Exchanges America/Italy) 1954/61; Jan De Vroom (CEO Altamira) 1953/55; Robin Dunn (Pite Son \& Fairweather) 1956/57; Dwight David Eisenhower (U.S.A. President) 1953/63; A.B. Ennis (Ennis \& Williamson s.r.1.) 1937/38 ; Featherston Furniture 1950/57; Financial Times 1961-1956/57; Glenn Fowler (The New York Times) 1952/75; Jordan R. Furneaux (The Observer) 1956/57-1952/75; Furniture Record 1956/57; Konrad Gatz (Detail) 1959/61; W. Geddes (T.D. Downing Company - Deliveries) 1953/54.

${ }^{34}$ Confederazione Nazionale Artigianato (National Handicrafts Confederation).

${ }^{35}$ SHERER, “Gio Ponti”, cit., p. 36; FALCONI, Laura, Gio Ponti. Interiors Objects Drawings 1920-1976, Milan, Electa, 2010, p. 45.

${ }^{36}$ Gio Ponti Archives, Milan, Correspondence.

${ }^{37}$ Published by Daria Guarnati editore, Milan, 1954, with the aim of presenting to an international public "The most complex personalities on the field of today's Italian art" (p. 1). The decision to ask an American intellectual such as Plaut to write the foreword is testimony to the deep relationship between Ponti and the US.

${ }^{38}$ PLAUT, James, "Expression of Gio Ponti”, in Espressione di Gio Ponti, Milan, Daria Guarnati, 1954, p. 8.

${ }^{39}$ Gio Ponti. Architecture, furniture, industrial design, interior design, Introduction by James S. Plaut, Herbert Read; paintings, graphic design photograms, exhibition design by Gyorgy Kepes. Boston, The Institute of Contemporary Art, 1954.

40 TAFURI Manfredo, Storia dell'architettura Italiana 1944-1985, Torino, Einaudi, 1982, pp. 5-46.

${ }^{41}$ BULEGATO, Fiorella and DELLAPIANA, Elena, Il design degli architetti in Italia 1920-2000, Milan, Electa, 2014, pp. 154-159.

${ }^{42}$ BASSI, Alberto, Italian Lighting Design. 1945-2000, Milan, Electa, 2004, pp. 40-49.

${ }^{43}$ DEBONI, Franco, Fontana Arte, Turin, New York, Allemandi, 2012, pp. 262-275.

${ }^{44}$ RICCINI, Raimonda and BASSI, Alberto, eds., Design in Triennale 1947-68. Percorsi fra Milano e Brianza, Cinisello Balsamo, Silvana, 2004, pp. 91-100.

45 The "goat and donkey straw toys" were produced by Emilio Paoli, Florence.

46 BASSIGNANA, Pier Luigi and MANZO, Luciana, eds., Bambole e non solo... Lenci: una storia torinese, Torino, Archivio storico, 2010.

${ }^{47}$ ROGERS, Meyric R., Italy at Work. Her Renaissance in Design Today, Rome, CNA, 1951, p. 49.

48 The Mediterranean cult was another recurrent theme in architectural literature before WWII in Italy (Ponti himself, Pagano and others) but also elsewhere; see Le Corbusier's references to southern European architectural culture in Carnets de voyage.

${ }^{49}$ PONTI, Gio, “Considerazioni su alcuni mobili”, in Domus 243 (February 1950), pp. 26-28.

${ }^{50}$ BULEGATO, DELLAPIANA, Il design, cit. p.155.

${ }^{51}$ DELLAPIANA, Elena, "La lunga marcia del design: La mostra Colori e forme della casa d'oggi, a Como, 1957”, in AIS design/ Storia e Ricerche, 3 (2014).

52 "Reatil Trade: Abroad at Home", Time, September 17 (1951); "With all the fanfare of a neighbourhood block party, Manhattan's R. H. Macy \& Co. this week threw open its doors to "Italy-in-Macy's, U.S.A.," a milliondollar sale of Italian imports spread out over an entire floor of its New York store. More than 25,000 people crowded into the show the first afternoon, were waited on by clerks decked out in Italian costumes, watched Italian craftsmen blowing glass, tooling leather, making ceramics. Other exhibits: a full-size Venetian gondola, models of Columbus' flagship, a reproduction of St. Peter's Church, and a donkey cart (lent by General George...); "Italian Fair at Macy's", Interiors CXI, 4, (November 1951), p. 14.

53 PONTI, Gio, “Omaggio a una mostra eccezionale”, in Domus, 253 (December 1950), p. 25; the article consists of 55 pages, in which each chapter of the exhibition is embellished with almost double the number of pictures of the items, showing a preference for the less traditional ones.

${ }^{54}$ MoMa Press Release Archives, New York, 0056_1951-08-23_510823-46.

55 JOHNSON, Philip, "Introduction" to 8 Automobiles. An Exhibition of motorcar design, New York, MoMA, 1951, p. 2; the exhibition held from August 28 to November 11.

${ }^{56}$ KAUFFMANN, Edgar, “Contemporary Italian design”, in Magazine of Art (January 1951), pp. 19-20.

${ }^{57}$ House and Garden, December 1950.

${ }^{58}$ MANGO, Roberto, “A portfolio from Italy”, in Interiors CXII, 5, (December 1952), pp. 74-111. 


\footnotetext{
${ }^{59}$ Ibid. 74.

${ }^{60}$ Ibid. 78.

${ }^{61}$ Ibid. 88.

${ }^{62}$ Ibid. 92.

${ }^{63}$ Ibid. 82.

${ }^{64}$ Ibid. 86.

${ }^{65}$ CASCIATO, "Between Craftmanship", cit. p. 20.

${ }^{66}$ NELSON, "Blessed are the Poor", cit. p. 71.

${ }^{67}$ PONTI, Gio, La casa all'italiana, Milan, Domus Editoriale, 1933.
}

${ }^{68}$ PONTI, Gio, "Italia a New York", in Domus 298 (September 1954), pp. 3-10, VERNET, David and DE WIT, Leontine, eds., Boutiques and Other Retail Spaces: The Architecture of Seduction, London, Routledge, 2007, pp. 88-93.

69 "Olivetti: design in Industry", Museum of Modern Art Bulletin, in conjunction with the Exhibition of the Work of Olivetti's company at the Museum of Modern Art from October 22 to November 20, 1952. The exhibition and Bulletin were designed by Leo Lionni in cooperation with the Department of Architecture and Design.

70 PEVSNER, Nikolaus, "At Aspen in Colorado", in R. BANHAM ed., The Aspen Papers. Twenty Years of Design Theory from the International Design Conference, London, Pall Mall Press, 1974, pp. 15-18; Getty Research Institute, Los Angeles, Special Collection, International Design Conference in Aspen records, series I, box 1 , folder 1 .

71 “The Energies of Italy. The resurgence of Italian Industry, expressed by some of Italy's best artists", in Fortune (January 1954), pp. 98-107; the Fortune edition was in turn praised in Domus (n. 291, 2/1954, p. 54), giving the merit to Leo Lionni and highlighting the participation of Enrichetta Ritter, one of the Domus' board members.

72 AUGSPURGER Michael, An Economy of Abundant Beauty: "Fortune" Magazine and Depression America Ithaca \& London, Cornell University Press, 2004; REILLY, Kevin S., Corporate Stories: Fortune Magazine and Modern Managerial Culture, Amherst, University of Massachusetts, 2004.

73 “The Energies", cit., p. 98.

${ }^{74}$ Ibid. p. 107. During these years the American interest in Italian creativity keeps on in visual arts too: an exhibition on Giorgio de Chirico at MoMA in 1955, another titled Painting in post-war in Italy 1945-1957, Columbia University, New York, 1957, with a preface by Lionello Venturi, and a series of exhibitions in private art galleries (De Chirico at Acquavella Gallery, New York, 1947; Afro, Catherine Viviano Gallery, New York, 1955 and 1960; Scialoja at Catherine Viviano Gallery, New York, 1956; Fontana, Martha Jackson Gallery, New York, 1961; Dorazio, Rose Fried Gallery, New York, 1954).

${ }^{75}$ Italy Creates, Rome-New York, Italian Ministry for Foreign Trade, 1953.

${ }^{76}$ Ibid. p. 3.

${ }^{77}$ Ibid. p. 7, from Washington Post, September 16, (1951).

${ }^{78}$ RUARK, Robert, "Rome was never like this...", in Esquire, January 1953, p. 48, with portraits of Italian actress ph. By Sam Shaw.

${ }^{79}$ Ibid. pp. 50-51.

${ }^{80}$ Ibid. p. 57.

${ }^{81}$ Modern by Singer, vernissage invitation, Monday $5^{\text {th }}$ November 1952 , New York, $32-38$ east (9 street), Gio Ponti Archives, Milan.

${ }^{82}$ Editorial, "La finestra arredata", in Domus, 298 (September 1954), pp. 17-20.

${ }^{83}$ Gio Ponti Archives, Milan. Both the correspondence and the drawings archives contain a number of testimonies to the contact between Ponti and the American Company.

${ }^{84}$ PONTI, Gio, "L'interesse americano per l'Italia", in Domus 292, (March 1954), pp. 56-72; Ponti, as Domus director, showed in turn a strong interest for American products and designers as the many dedicated articles and editorials demonstrate.

${ }^{85}$ Ponti attributed to Raymond Loewy the statement that in Italy "better than anywhere else" architects were industrial designers; ibid. p. 56. 
${ }^{86}$ Ibid. p. 58.

${ }^{87}$ GUIDA, Ermanno, Roberto Mango. Progetti, realizzazioni, ricerche, Naples, Electa Napoli, 2006.

${ }^{88}$ Patent U.S.A. $\mathrm{n}^{\circ}$ 3908604, 1953 December 28, "Improvements in chair formed by two independent and superposable elements".

${ }^{89}$ As in the picture shot of Audrey Hepburn sitting on a sun-flower chair wearing a wide-brimmed Italian straw hat, Vogue, May 1954, p. 73.

${ }^{90}$ CORDONI, Claudio, Maurizio Tempestini. Interior Architect (1908-1960), Florence, Edifir, 2010.

${ }^{91}$ ROGERS, Italy at Work, cit. p. 20.

${ }^{92}$ MoMA Press Release Archives, 0132_104j; HUXTABLE, Ada Louise, "Post-War Italy: Architecture and Design", in Art Digest, 28, 18 (1954), pp. 6-8; Ead., "The Modern Movement in Italy", in Interiors, CXIII, 5, (December 1953), pp. 74, 151-154. The article includes pictures of Terragni's, Figini \& Pollini's, Nervi's architectures and the Memorial of the Ardeatine Trench, a mix of architecture and sculpture by Aprile, Calcaprina, Fiorentino, Perugini.

93 Ibid. p. 154.

${ }^{94}$ PONTI, Gio, “Senza aggettivi”, in Domus, 268, (March 1952), p. 1.

95 MENDINI, Alessandro, “Gio Ponti 1891-1979”, in Domus, 599, (October 1979), p. 1.

96 PULOS, Arthur J., The American Design Adventure, Cambridge, MIT Press, 1988, pp. 110-161; on the influences of the American consume system in Europe, DE GRAZIA, Victoria, Irresistible Empire: America's Advance Through Twentieth-Century in Europe, Harvard, Belknap Press, 2005, pp. 371-391.

${ }^{97}$ On the sequence of exhibitions of "Italian things", DELLAPIANA, Elena, "Dalla Casa all 'Italiana all'Italian Style. La creazione del Made in Italy. 1920-1995", in G. ERBACCI, L. FIORUCCI, G. LEVI, A. ROSSI COLAVINI, V. SOGARO eds., Ceramiche e arti decorative del Novecento. Vol. II, Verona, Edizioni03, 2017, pp. 59-88.

98 "Dramatic Decade of Italian Style", Life, December 1 ${ }^{\text {st }}, 1961 ; 15$ pages with photos by Mark Kauffam for Life and a double cover. This academic and popular focus on Italian design was brought to a climax in 1972, with the huge exhibition promoted by MoMA and curated by Emilio Ambasz; AMBASZ, Emilio, ed., Italy: the new Domestic Landscape. Achievements and Problem of Italian Design, New York, MoMA, 1972.

Fecha de recepción: 04-10-2017

Fecha de revisión: 30-11-2017

Fecha de aceptación: 18-12-2017 